\title{
Terminological distinctions of 'control': a review of the implications for management control research in the context of innovation
}

\author{
Andrea Fried $^{1,2}{ }_{\mathbb{B}}$
}

Published online: 30 December 2016

(C) The Author(s) 2016. This article is published with open access at Springerlink.com

\begin{abstract}
The article reviews the terminological distinctions (e.g. action and result control, interactive and diagnostic control) used for control in twenty-five empirical studies on management control in the context of innovation. The terminological distinctions are classed in three categorizations. These are (a) the types of managerial control, (b) the design and use mode of managerial control instruments and (c) the enabling and constraining character of managerial control instruments. By analyzing the categorizations, it becomes evident that there are two, almost independent ontological streams shaping the empirical field: the determinist perspective and the voluntarist perspective of management control with different understandings of contingency. The 'ideal fit' approach to contingency of the determinist perspective adds little cumulative knowledge to the field of management control in the context of innovation. Therefore, the article suggests to strengthen the voluntarist perspective and to develop a 'quasi fit' interpretation of contingency. The agenda for prospective research in management control in the context of innovation includes to investigate deviant and repair behavior related to management control systems (MCS) in innovating activities, to understand MCS as dependent as well as independent variable and to explore the role of MCS in economizing innovative activities.
\end{abstract}

All papers listed in the references which are marked with * belong to the remaining study sample (see also "Appendix 2") after the systematic literature search.

¿ Andrea Fried andrea.fried@liu.se

1 Department of Management and Engineering, Business Administration, Linköping University, Linköping, SE 581 83, Sweden

2 Otto Schott Institute of Materials Research, Department of Metallic Materials, Friedrich-Schiller-University of Jena, Löbdergraben 32, 07743 Jena, Germany 
Keywords Contingency perspective $\cdot$ Determinism $\cdot$ Distinction - Innovation · Management control $\cdot$ Use mode $\cdot$ Voluntarism $\cdot$ Deviance

JEL Classification M10 - M40 - O32

\section{Introduction}

This article reviews the existing literature on management control and innovation in view of the terminological distinctions chosen by the authors in the field. It expands on recently published reviews (Chenhall and Moers 2015; Haustein et al. 2014; Moll 2015) by further explaining the argumentation mechanisms of the chosen distinctions and by formulating streams of theoretical development. It does this for three reasons.

The first reason is to show that terminological distinctions matter. Much of research in management control starts with drawing distinctions, for instance, between administrative control, self-control and social control (Hopwood 1976), between technocratic control and socio-ideological control (Alvesson and Kärreman 2004) or between result control, action control, personnel control and cultural control (Merchant and Van der Stede 2012; for an overview see Haustein et al. 2014).

Management control is currently facing an increasing interest in the topic of innovation referring to manifold terminological distinctions. Therefore, it appears meaningful to analyze these distinctions in more detail. To this end, the review grounds its analysis in the logic approach by Spencer Brown. Although the article does not apply the logical approach as such, it refers to the instruction "draw a distinction" (Spencer Brown 1972, 3). Theory development depends on how distinctions are formed since they produce an inner (the observed and described state) and an outer side (the other, unmarked state) (Luhmann 1988). Thus, the article describes the applied distinctions ${ }^{1}$ and discusses their implications for future research in management control and innovation by identifying opportunities for further theoretical developments in the field.

The second reason is the suitability of empirical investigations for studying management control with the aim to discover its "unmarked state" (Spencer Brown 1972). Empirical studies in the field of MCS investigate informal control mechanism as well as formalized procedures and systems using information to maintain or alter patterns in organizational activities (Bisbe and Otley 2004). In the context of innovative, uncertain environments empirical studies ask in addition how MCS can become "flexible and dynamic frames adapting and evolving to the unpredictability of innovation, but stable to frame cognitive models, communication patterns, and actions" (Davila et al. 2009a, 327; cf. Bourne 2014; Davila et al. 2009b; Simons 1995; Ouchi 1979). Innovation is thereby understood as an outcome of processes of invention, development, and implementation of new ideas (Garud et al. 2013).

Empirical investigations are important to develop the field of management control in contexts of innovation. They show how management control is realized and demon-

1 The term distinction is used in accordance with Spencer Brown (1972) and Luhmann (1988). To draw a distinction is a philosophical process where a boundary is set around something recognizing a difference and separating it from everything else. 
strate which consequences are triggered by instruments of managerial control (Gavetti et al. 2012; Hopwood 1983; Miller and Power 2013). Furthermore, present empirical investigations in management control and innovation refer at least to one distinction (later called categorization).

The third reason is that there are three recently published literature reviews on management control and innovation which leave room for further theoretical developments. Haustein et al. (2014) review the literature in the Journal of Management Control to extract eleven hypotheses about contingency factors for innovative companies (external, organizational and innovation related characteristics) and their relation to results, action, personnel and cultural control (Merchant and Van der Stede 2012). As a result, Haustein et al. suggest a number of hypotheses to test, for instance, how the different types of control are associated with a differentiation strategy, technological complexity in innovative environments, or the degree of decentralization.

In Accounting, Organizations and Society, Chenhall and Moers (2015) show likewise a preference for the contingency perspective and assess how the creation and implementation of MCS supports innovation. They start by referring to the discourse in which management control was once considered unsuitable for an innovation context but emphasize that this perspective has changed nowadays. Chenhall and Moers introduce the reader to MCS for product development, to performance evaluations and product development, to informal and formal ways of control for managing innovation, and to innovation-related aspects in the Balanced Scorecard (Kaplan 2009) and in the 'Levers of Control' framework (Simons 1995). They also describe how target costing, life-cycle costing or activity-based management influence product development. Based on these discussions, Chenhall and Moers compile several suggestions for future research. They recommend to focus on the evolution of control processes and information flows in innovative environments, to investigate MCS applied in service innovations and in innovative business models, to study managerial control systems used by intrapreneurs compared to entrepreneurs and finally to consider the issue of open innovation.

For Management Accounting Research Moll introduces a special issue on innovation and product development (Moll 2015). In her review, she distinguishes between studies which understand management accounting as incompatible for new product development (NPD) environments and those, mainly more recent studies that understand them as compatible. Moll presents studies which investigate management control as a package compared to those studies which solely focus on single elements of control such as budgets or cost management. She further pinpoints studies which put central the collaborative aspects of management control and innovation. The article finishes with the statement that little theory building has been done, even in the introduced special issue itself. In the end, Moll recommends to investigate incentive systems, packages of management control, portfolios of research and development (R\&D) projects, collaborative environments and different cultural settings.

The main recommendations arising from these reviews are linked to further investigation of different empirical objects, for instance the suitability of different business models, incentive systems, and degrees of decentralization to the context of innovation. These research interests are typically framed by the 'ideal fit' idea of the contingency 
approach as promoted by Chenhall (2003), Chenhall and Moers (2015) or Haustein et al. (2014) for the field of management control. Besides criticism regarding its limited scope and ruling interpretation (e.g. Chapman 1997; Cowton and Dopson 2002; Hewege 2012), the contingency perspective in management control has contributed to a body of research that shaped the way we investigate management control. In the context of innovation-described as an uncertain, complex environment (Bourne 2014; Pfister 2014) - the arguments, however, "that contingent variables are not adequate to explain all the drivers of control systems" and that the business environment is "not a static factor to be easily adapted to" (Hewege 2012,6) double their weight. Uncertainty in innovation processes results from its non-routine character. Hence, further theory building needs to be done.

The following review reconstructs for that purpose the drawn distinctions in management control in the context of innovation and asks: What are the theoretical limitations of the chosen distinctions for research on management control in contexts of innovation? How should the theoretical agenda in management control in contexts of innovation be advanced in view of these limitations?

The article provides three contributions. First, it shows that the chosen distinctions of control for investigating the context of innovation matter. The second contribution consists of the identification of the limited explanatory power of the ruling interpretation of contingency and strengthens instead the 'quasi fit' meaning of contingency (Donaldson 2001; Volberda et al. 2012). Third, the article recommends to further investigate MCS in the context of innovation as dependent variable in order to make a sustained effort in characterizing MCS in the context of innovation themselves.

The paper is structured as follows. The next section analyzes twenty-five studies by describing and assessing the main categorizations they use to structure the empirical field: (a) types of managerial control in the context of innovation, (b) design and use modes of managerial control instruments in the context of innovation, as well as (c) the enabling and constraining character of managerial control instruments in the context of innovation. The three categorizations found frame the marked and unmarked state of research in management control and innovation. The agenda for future research in management control encompasses therefore three major directions by learning from innovation research, technology research and accounting research alike. The resulting mission is described in Sect. 3 as an agenda for further research in management control and innovation. The paper is summarized in the Sect. 4.

\section{Empirical studies in management control and innovation}

This section provides an overview of the empirical research in management control and innovation within the field of business and management. The objective is to categorize the empirical field and to draw conclusions for future theoretical developments. Before the findings are presented the following section describes how the existing empirical material is approached by assessing its distinctions and developing categories. The search strategy for the systematic literature review is presented beforehand. 


\subsection{Design of literature review}

\section{Search strategy}

The articles analyzed in this review were acquired by systematically searching for literature within the discipline of business and management in August 2016. By using the search mode Boolean/Phrase the following string was applied for searching within publication abstracts: $\mathrm{AB}$ (AB "management control" AND AB innovation) OR AB (AB "management control" AND AB "research and development OR r\&d") OR AB (AB "management control" AND AB "new product development"). The criteria for the inclusion and exclusion of search terms in the field of management control and innovation were defined as follows. While focusing on management control, the search terms management accounting, performance measurement and budgeting as potential synonyms for MCS were not included. As indicated in the introduction, the article follows an Anglo-American understanding of MCS where not only the design of an appropriate accounting system is central (Guenther 2013). Instead, it takes a wider view and includes more indirect control mechanism as well (Haustein et al. 2014). For this reason, articles which refer to management accounting and management accounting systems solely were excluded, for instance those by Ferreira et al. (2010) or Ittner and Larcker (1998). Moreover, since innovation is defined in this article as an outcome of processes of invention, studies setting NPD or research and development instead of innovation central are included in the literature review such as Bonner (2005). Articles emphasizing a processual perspective on innovation such as learning (e.g. Widener 2007) were not taken into account. There are a number of empirical studies pinpointing the consequences of management control namely formal, personnel, behavioral control for individual creativity and intrinsic motivation in uncertain, innovative environments (for instance Adler and Chen 2011; Amabile 1998; Breunig et al. 2014; Collins and Amabile 1999; Randle and Rainnie 1997). These studies deliver reasonable insights into the discussion of management control and innovation both by emphasizing the autonomy from managerial control as critical to intrinsic motivation and by realizing that some forms of control like personnel control are most effective in environments of high task uncertainty and complexity. However, the appearance and change of managerial control and related systems in the different contexts of innovation as well as in which ways managerial control intersects with innovating practices, decision making and power structures can hardly be explored by studies at the level of individual creativity and motivation only (see for a similar discussion cf. Hopwood 1983 and Hopwood 1978). For this reason, these studies were not included.

The database UniSearch was approached as the main search entry. UniSearch is a library all-in-one service for searching articles, books and more through a single access point. By this means, the search string does not need to be adapted to suit the specific requirements of the different databases. The material types searched were academic journals and books. The search returned 104 results in the three databases Business Source Premier, EconLit and ScienceDirect. "Appendix 1" provides an overview of the journals that revealed results according to the search string. In a next step UniSearch allows to limit the results to the publication language English. Furthermore, it permits to specify further 'subjects' which are keywords defined by authors or are controlled 
vocabularies defined by publishers and librarians. By choosing the subject 'empirical studies' it was possible to detect the studies of interest for the article. At this stage, the sixty-six remaining publications from the systematic database search were manually assessed. They were finally limited to nineteen by excluding publications for which the topic product innovation and management control was not the central research question (e.g. innovation strategy, innovation culture, innovation values, managerial innovation, service innovation or control solely understood as hierarchy) or if the publication was still of pure conceptual nature.

In addition to the systematic database search several journals were manually approached since it was known that these sources had published papers on the topic or were recommended by experts in the field: Industrial Marketing Management, Organization Science, Scandinavian Journal of Management, International Journal of Networking and Virtual Organisations, Review of Managerial Science and Omega. This search revealed another seven articles. In total, the following literature review is based on twenty-five publications (study sample).

\section{Formation of categories}

Observing the empirical field of management control in contexts of innovation without distinctions is impossible. Once a distinction is set it delivers on the one hand a decision which information shall be gained and transformed and which information not (the alternative would be chaos) (Luhmann 1988). An observation is a differentiation in which some things are omitted (unmarked state, 'blind spot') and others are highlighted (marked state) (Spencer Brown 1972). The delimitation of a marked state as well as the insinuation of an inner order is always dependent on the observer (here: the researcher in management control) and on his or her motives and objectives (Spencer Brown 1972). Benefits and pitfalls of "draw a distinction" (Spencer Brown 1972, 3) for the acquisition and transformation of empirical data are not easily visible. The marked state produces asymmetries which are widely taken for granted. These asymmetries are only reversible by replacing the underlying distinctions with novel distinctions which produce, of course, new asymmetries themselves. Hence, research in management control in the context of innovation needs to take distance, for instance, in literature reviews to challenge established distinctions.

As it counts for this article, distinctions are often presented as categories. By defining clear criteria for membership categories consider objects as being equivalent and tend to be viewed as separated from each other (Rosch 1998). They provide information so "that the perceived world comes as structured information rather than as arbitrary or unpredictable attributes" (Rosch 1998, 252). Authors usually introduce categories by prototypical members (Rosch 1998). Categories have a crucial function. They predetermine results and recommendations of empirical and conceptual studies whilst an unmarked state is inevitably inscribed. For exploring the marked and unmarked state it is necessary to have a closer look at the categorizations being used in empirical studies of management control and innovation. A categorization is thereby an entirety of categories, for instance, market, accounting and non-financial measures or for-profit and not-for-profit organizations. 
Table 1 Cat 1 studies and their main control distinctions

\begin{tabular}{ll}
\hline Authors & Main control distinctions \\
\hline $\begin{array}{l}\text { Abernethy and Brownell (1997) } \\
\text { Bonner (2005) }\end{array}$ & $\begin{array}{l}\text { Accounting control, behavior control, personnel control } \\
\text { Output control, process control, team reward control }\end{array}$ \\
Bonner et al. (2002) & $\begin{array}{c}\text { Formal control, formal output control, interactive } \\
\text { control, process control }\end{array}$ \\
Cardinal (2001) & Behavior control, input control, output control \\
Chenhall et al. (2011) & Formal control, informal control \\
Kuschel et al. (2011) & Direct control, indirect control \\
Li et al. (2005) & Strategic control, financial control \\
Lukas et al. (2002) & Formal control, informal control \\
Omta et al. (1994) & Personnel control, resource control, process control \\
Richtnér and Åhlström (2010) & Formal control, informal control \\
Rijsdijk and van den Ende (2011) & Clan control, outcome control, process control \\
Smets et al. (2016) & Input control, process control, output control \\
\hline
\end{tabular}

\subsection{Categorizations of empirical studies in management control and innovation}

Three major categorizations with different explanatory power were found in empirical studies of management control and innovation producing different kinds of marked states. Categorization 1 (Cat1) highlights studies which investigate the fit of different types of managerial control for the context of innovation. Categorization 2 (Cat2) represents studies which distinguish between the design mode and the use mode of managerial control instruments in the context of innovation. Categorization 3 (Cat3) summarizes studies that are referring to the enabling and constraining character of MCS in the context of innovation. Except for one article, these empirical studies either base their findings on Cat 1 or on Cat2. An extended overview with sector and country investigated, empirical methods used in detail, their thematic focus and important findings besides their categorization can be found in "Appendix 2".

Following, prototypical members representing the respective categorization are presented to define its marked and unmarked state.

\section{Categorization 1: Types of managerial control in the context of innovation}

As depicted in Table 1, for categorization 1 (Cat1), there were twelve articles found which base their empirical investigations on the distinction of different types of control.

In general, Cat1 studies assume that the implementation of a specific control element or control package causes a specific innovation performance. They trust in the fit of different types of managerial control elements or packages for the context of innovation. Cat 1 studies refer to contingency in a way that associates the mission of management control with the identification and matching of specific MCS elements or packages to certain defined circumstances.

To exemplify how the 'ideal fit logic' of the Cat 1 studies works some of the studies are presented in more detail in the following. Bonner (2005), for instance, investigated 
the degree of customer interaction when output control, process control and team rewards control are used in NPD projects. Bonner (2005) follows the idea that each type of control directs project teams in a specific way: either to organizational processes or to customers. According to his findings, customer interactivity is increased by output control and control via team rewards. By contrast, the interaction with customers is decreased when organizations decide for a strong focus on process control in NPD projects without combining it with output control. In an earlier study, Bonner et al. (2002) investigated the relation between different control mechanism (formal control, output control, interactive control, process control) and NPD project performance expressed by the degree of the NPD project's innovativeness and the degree how the project contributes to the company's product program. The findings of the study show inter alia that there is a negative relation between process control and NPD project performance, no relation between output control and project performance but a positive influence on NPD project performance when interactive control was installed at the beginning of the project.

Cardinal (2001) distinguishes between input, behavior and output types of control. The main finding is that input, behavior, and output control enhance radical innovation whereas input and output controls also enhance incremental innovation. Consequently, she states that incremental and radical innovation should be managed in the same way.

In a collaborative situation of open innovation, Kuschel et al. (2011) recommend to release direct forms of control like an intellectual property strategy in favor of more indirect ways of control, for instance by an active facilitation of spin-offs that might be re-acquired when innovations are mature enough, by open standards and generative technological IT-platforms or by mobilizing a critical mass of active and participating users to create value of innovative products.

Four propositions about the impact of informal control exercised by a company's top management were formulated by Richtnér and Åhlström (2010). Informal control can positively affect knowledge creation in the later phases of a NPD project and the creation of explicit knowledge. It can negatively affect knowledge creation in the early phases of a NPD project as well as the creation of tacit knowledge.

Rijsdijk and van den Ende (2011) point out that the combination of output and clan control is the most effective in positively influencing the performance of NPD processes. Informal and formal controls are explicitly not seen as potential substitutes. They sound a cautionary note about combinations of different kinds of control which may result in synergistic or conflicting effects in view of NPD outcomes.

In summary, supporting Moll (2015) and her concerns about the low theoretical explication of management control and innovation, there are only three of the Cat1 studies which mention explicitly their grounding in an organization theory. Cardinal (2001), Richtnér and Åhlström (2010), Rijsdijk and van den Ende (2011) take up a contingency approach (originally Burns and Stalker 1961; Lawrence and Lorsch 1967; Woodward 1965). Even if not explicitly stated, the remaining studies take on the same perspective.

Cat1 studies refer to different types of control as a starting point for empirical investigations, taking up an argumentation of the following kind: "too much of the wrong type of formal control may constrain the team's creativity, impede their progress, and injure their ultimate performance" (Bonner et al. 2002, 234). 
Fig. 1 Cat 1 studies and the search for the 'ideal contingency fit'

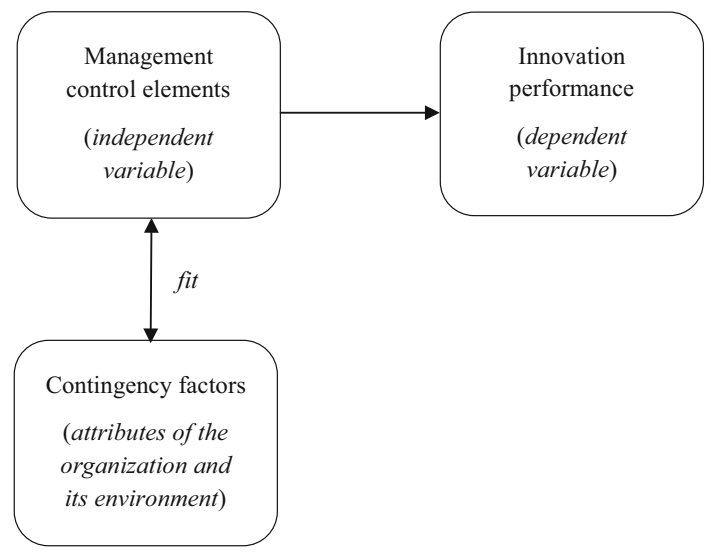

As Fig. 1 generalizes, empirical investigations of Cat 1 studies assume that an ideal fit between situational requirements and MCS is necessary for the success of innovation. The contingency paradigm emphasizes that there are specific situational factors that can affect the direct relationships between independent variables (MCS) and dependent variables (innovative performance) in studying organizational behavior. In general, there are two types of fit - horizontal and vertical fit (Wright and Snell 1998). The horizontal fit describes the fit among the management control elements within a MCS (MCS as a package; Otley 1980). Cat1 studies focus on the vertical contingency fit that covers the alignment of MCS with the strategic objectives of the firm (e.g. product differentiation). Contingency fit means that there is for each contingency variable a MCS package or element that constitutes fit and delivers the highest possible innovation performance for this contingency variable (Van de Ven and Drazin 1985).

The contingency perspective as interpreted by Cat1 studies in the field of management control and accounting has already been discussed by Otley (2016). By stating that contingency studies leave "no obvious starting point for an explanation of an increasing body of often contradictory results" (Chapman 1997, 189), reviewers started to discover the unmarked state of this theoretical perspective in management control (Argyris 1972; Child 1972; Hendry 1979; Smith and Nichol 1981). In particular, Bisbe and Otley state that contingency research provides "inconsistent findings regarding the relationship between formal MCS and product innovation" (Bisbe and Otley 2004, 710). Management accounting and control systems are "often operationalized as a purely formal and routine technology, with expectations of it often couched in terms of its presence in stable settings, or absence in unstable one" (Chapman 1997, 190). Bisbe and Otley even argue that "some authors have pointed to the different styles of use of formal MCS... or the different roles of MCS... as explanations for these apparently inconsistent studies" (Bisbe and Otley 2004, 710). As far as studies of management control in the context of innovation are concerned, the observation that cumulative findings and replications studies are rare cannot be justified simply by an imbalanced use of qualitative and quantitative studies (as Otley (2016) states for management control in general) as "Appendix 2" proves. 
In my reading, Cat1 studies have a limited contribution to the theoretical corpus in management control in the context of innovation for other reasons. On the one hand, contingency is epistemologically seen the knowledge about all knowledge being relative- 'it can always be completely different'. This is an important lesson for the field of management control and shows that closed and simultaneously universal theories are not possible in themselves (Luhmann 1984). Hence, Cat1 studies remind the community of management control researchers that the design of MCS as such matters and influences the behavior in and of organizations.

On the other hand, however, doubts remain. First, within the 'ideal fit' interpretation of the contingency perspective in management control it is left open how innovating organizations can be described by an inevitably limited number of variables (contingency factors) considering (a) the bounded rationality of human cognition (Simon 1991) and given that organizations are (b) in essence open systems which consist by definition of more variables than one can assume (Berry et al. 2009; Thompson 2003). Innovation and the research on contingency factors for an ideal fit seem to be mutually exclusive. Contingency approaches obviously work for closed systems where a limited number of controllable variables and a predictable global and task environment enable a determined system (Berry et al. 2009; Thompson 2003). For the context of innovation described as a complex and uncertain environment the 'ideal fit' of contingency seems to be an inappropriate description of organizations as open systems.

Second, the question appears to which extent a specific organizational behavior is in fact inscribed in the design of MCS (for instance, result control enhances innovation). Designers of MCS suppose a certain impact of the MCS on behavior in its context of use (Fried 2010; Fried et al. 2013). However, Cat1 studies hardly take into consideration that the design and the actual use of MCS in the context of innovation differ and assume that a MCS constantly produces the same output. This way, the focus of Cat1 studies constitutes a deterministic view on managerial control and innovation. MCS are seen as an independent variable which are not subject of enactment or can 'drift' as Quattrone and Hopper (2001) describe. The following categorization 2 takes up however the analysis of the use mode and frames research in the field of management control and innovation from a voluntarist point of view.

\section{Categorization 2: Design and use mode of managerial control instruments in the context of innovation}

In categorization 2 (Cat2), there were twelve empirical studies found focusing either on the use or explicitly on the distinction between the design and the use of managerial control instruments in the context of innovation (see Table 2).

Eight of the Cat2 studies (Artto et al. 2011; Bedford 2015; Bisbe and Malagueño 2009; Bisbe and Otley 2004; Chiesa et al. 2009; Davila et al. 2009a; Lopez-Valeiras et al. 2015; Pfister 2014) base their empirical efforts explicitly on the Levers of Control framework developed by Simons (1995). The Levers of Control framework distinguishes two different modes of MCS' usage: diagnostic use and interactive use. It emphasizes that interactive control systems are measurement systems that are used to direct attention to changing information and their strategic assessment by senior managers. Interactive control systems shall support the formation of emergent strategies by intensifying opportunity-seeking and learning (Bisbe and Otley 2004). In contrast, 
Table 2 Cat2 studies and their main control distinctions

\begin{tabular}{|c|c|c|}
\hline Authors & Main distinctions & Theoretical framework \\
\hline Artto et al. (2011) & $\begin{array}{l}\text { Diagnostic use of MCS, } \\
\text { interactive use of MCS }\end{array}$ & $\begin{array}{l}\text { Levers of control framework } \\
\text { (Simons 1995); theories of } \\
\text { organization design and } \\
\text { integrative organizational } \\
\text { arrangements (Hobbs and } \\
\text { Aubry 2008) }\end{array}$ \\
\hline Bedford (2015) & $\begin{array}{l}\text { Diagnostic use of MCS, } \\
\text { interactive use of MCS }\end{array}$ & $\begin{array}{l}\text { Levers of control framework } \\
\text { (Simons 1995) }\end{array}$ \\
\hline Bisbe and Malagueño (2009) & $\begin{array}{l}\text { Diagnostic use of MCS, } \\
\text { interactive use of MCS }\end{array}$ & $\begin{array}{l}\text { Levers of control framework } \\
\quad \text { (Simons 1995) }\end{array}$ \\
\hline Bisbe and Otley (2004) & $\begin{array}{l}\text { Diagnostic use of MCS, } \\
\text { interactive use of MCS }\end{array}$ & $\begin{array}{l}\text { Levers of control framework } \\
\quad(\text { Simons 1995) }\end{array}$ \\
\hline Chiesa et al. (2009) & $\begin{array}{l}\text { Diagnostic use of MCS, } \\
\text { interactive use of MCS }\end{array}$ & $\begin{array}{l}\text { Levers of control framework } \\
\quad(\text { Simons 1995) }\end{array}$ \\
\hline Davila (2000) & Design of MCS, use of MCS & $\begin{array}{l}\text { Concept of uncertainty } \\
\text { (Galbraith 1973) }\end{array}$ \\
\hline Davila et al. (2009a) & $\begin{array}{l}\text { MCS roles, MCS adoption } \\
\text { reasons }\end{array}$ & $\begin{array}{l}\text { Levers of control framework } \\
\text { (Simons 1995); growth } \\
\text { model (Greiner 1972); } \\
\text { concept of adaptive routines } \\
\text { (Weick et al. 1999) }\end{array}$ \\
\hline Janssen et al. (2011) & $\begin{array}{l}\text { Use of MCS (instrumental, } \\
\text { symbolic, conceptual), design } \\
\text { of MCS (balance, coherence, } \\
\text { adaption, user know-how) }\end{array}$ & $\begin{array}{l}\text { Behavioral accounting theory } \\
\text { (Bruns 1969); multilayer } \\
\text { performance management } \\
\text { framework (Möller et al. } \\
\text { 2011) }\end{array}$ \\
\hline Kivisaari (1991) & $\begin{array}{l}\text { Central control activities } \\
\text { (corporate management), } \\
\text { decentral control activities } \\
\text { (business management) }\end{array}$ & $\begin{array}{l}\text { Open communication systems } \\
\text { (Kanter 1994); integrative } \\
\text { approach of differentiation } \\
\text { and interdependence } \\
\text { (Goold and Campbell 1988) }\end{array}$ \\
\hline Lopez-Valeiras et al. (2015) & $\begin{array}{l}\text { Interactive use of MCS, } \\
\text { diagnostic use of MCS }\end{array}$ & $\begin{array}{l}\text { Levers of control framework } \\
\quad(\text { Simons 1995) }\end{array}$ \\
\hline Pfister (2014) & $\begin{array}{l}\text { Diagnostic use of MCS, } \\
\text { interactive use of MCS }\end{array}$ & $\begin{array}{l}\text { Levers of control framework } \\
\quad(\text { Simons 1995) }\end{array}$ \\
\hline Westling (2002) & $\begin{array}{l}\text { Formal use of MCS, informal use } \\
\text { of MCS }\end{array}$ & $\begin{array}{l}\text { Loose coupling approach } \\
\text { (Orton and Weick 1999) }\end{array}$ \\
\hline
\end{tabular}

diagnostic control systems are formal feedback systems and "the backbone of traditional management control" (Simons 1995, 59) to guarantee the implementation of the intended strategy. Diagnostic control systems are used to monitor organizational outcomes and to ensure the correction of deviations (Simons 1995). Thus, interactive MCS are considered to be perfect for the context of innovation.

Besides the eight Cat2 studies which put Simons (1995) central, Janssen et al. (2011), Davila (2000), Davila et al. (2009a), Kivisaari (1991) and Westling (2002) also pay attention to the use mode in the context of innovation and the "actual utilization of 
information obtained" (Janssen et al. 2011, 107) from MCS. In summary, Cat2 studies seem to either concentrate on the question which kind of innovation management mode, intensity or project characteristics suits the interactive use. Or, they investigate different elements of MCS and their interactive usage.

Bedford (2015), for instance, examines Simon's framework across different modes of innovation known as exploration and exploitation. His main findings are that diagnostic and interactive control approaches independently enhance performance of organizations specialized in one of the innovation modes whereas they have complementary effects in ambidextrous organizations.

Bisbe and Malagueño (2009) find out that the choice of an interactive MCS depends on the company's innovation management mode. The product innovation output as such is influenced by the innovation management mode and by interactive management accounting and control systems (MACS) featuring similar cognitive models and information priorities. Eventually, similarity in patterns between the innovation management mode and MACS tend to not apply for the innovation output.

The specific relationship between the interactive use of MCS and successful innovations was identified by Bisbe and Otley (2004) as an important research question. They found that an interactive use of MCS most likely favors innovation only in lowinnovating firms, while the effect is the opposite in high-innovating firms. Moreover, Bisbe and Otley describe two ways how the interactive use of MCS can be realized: in a moderating or mediating style of use. A moderating style of use means that MCS serve as a forum to involve organizational members in an ongoing face-to-face dialogue to cope with non-routine, multi-disciplinary tasks in processes of NPD. When MCS are used in a mediating way they shall avoid dysfunctional extremes of innovative activities (too much innovation or too low innovation). According to their study, a positive impact on product innovation was found only for the moderating style of use.

Davila (2000) could show a strong diversity in the usage of MCS depending on the characteristics of product development projects in the medical devices industry. Characteristics of product development projects depend on their technology focus, market and project scope. According to Davila's case studies, prototyping replaces MCS when uncertainty evolves from the technology focus. When uncertainty elicits from the project scope or the marked scope MCS are a suitable tool to lower uncertainty by proving information instead of measuring goal divergence. Beyond this, Davila (2000) points out in his findings that project managers rely mainly on non-financial measures and less on traditional accounting measures to reduce uncertainty.

Janssen et al. (2011) focus on the design and use of innovation metrics in product innovation processes and state that the coherence and adaptation of innovation metrics have no significant impact on their conceptual (thus, interactive) use. Top performers measure immaterial inputs, quality aspects, project progress, output and outcome more often than low performers. Kivisaari (1991) concentrates on dilemmas in control of divisional R\&D activities in large companies. Reinforcing central control in R\&D prerequisites high quality interaction between corporate and business management. In traditional practices and structures not supporting change, strict central control over $\mathrm{R} \& \mathrm{D}$ is difficult to realize.

Lopez-Valeiras et al. (2015) run a study similar to Bedford (2015) about different types of innovation with the result that interactive MCS are able to synchronize and 
adapt process innovations with a positive effect on financial performance. Interactive MCS have a positive influence on organizational innovations but these innovations do not have a provable effect on financial performance.

Beside the empirical objects of innovation metrics, budget and decentralization in the context of innovation Westling (2002) asks about the balance of control and innovation, in particular the importance of informal and formal face-to-face meetings in complex product developments. Informal meetings facilitate the perception of complex and ambiguous issues. Formal meetings elevate and enter the defined issues into a formal existence. In line with the arguments scrutinizing the contingency perspective of Cat1 studies, the readers' attention should be on Westling (2002). Westling refers to the social-technical discourse on non-routine work. In doing so, he challenges the dichotomous distinction between formal and informal types of control by illustrating how meetings can be identified along a continuum that varies with the amount of discipline that is expected from a participating individual. Based on Goffman's work on social order (Goffman 1963), Westling describes how some meetings "are elevated into systems of substantive rules, and become law. Others, equally binding when it comes to face-to-face interaction, govern the ceremonial behavior towards others that is encoded etiquette. The ultimate penalty for breaking the rules is harsh" (Westling 2002, 22). By using a different ontological orientation, this study is an important example for how the contest of existing categorizations can lead into a multifaceted research.

Chiesa et al. (2009) investigate the front-end of radical innovation projects. They found flexible and social control management systems as most suitable in the early phases of the innovation process whereas at later stages of the innovation process diagnostic control activities were preferably in use. Remarkably, Chiesa et al. (2009) discuss the impact of contingencies as the Cat1 studies do but understand contingency more in its initial interpretation. Instead of asking for the ideal fit of contingency factors and MCS for the best innovation performance possible they investigate four innovation projects and turn the logic of contingency by identifying those variables which distinguish the cases from each other. Four contingency variables (size, origin of innovation, organizational structure and governance approach) are specified and limit the comparability of the case. The interpretation of contingency takes here into account that there is no universal solution for management control in the context of innovation.

Like the other Cat2 studies, the study by Chiesa et al. (2009) can serve as an example for a voluntarist point of view in the discourse of management control and innovation. In contrast to the determinist perspective which believes that MCS directly shape behavior, Cat 2 studies seem to agree with the voluntarist viewpoint that humans can also intend as well as influence the social effects of a MCS. MCS are seen as a dependent variable. Thought ahead, the consequence is that a focus on MCS as such is as important as the enactment of them. Consequently, as for instance Bisbe and Malagueño (2009) and Bisbe and Otley (2004) started to investigate, more empirical studies should pay attention to the ways how organizations make MCS suitable for the context of innovation.

In a nutshell, one can conclude that Cat 2 studies fill the unmarked state of Cat 1 studies and vice versa. There is, interestingly, only one Cat 2 study that points out 
Table 3 Cat 3 studies and their main control distinctions

\begin{tabular}{|c|c|c|}
\hline Authors & Main distinctions & Theoretical framework \\
\hline Bisbe and Malagueño (2009) & $\begin{array}{l}\text { Diagnostic use of MCS, } \\
\text { interactive use of MCS }\end{array}$ & $\begin{array}{l}\text { Levers of control framework } \\
\text { (Simons 1995) }\end{array}$ \\
\hline Bisbe and Otley (2004) & $\begin{array}{l}\text { Diagnostic use of MCS, } \\
\text { interactive use of MCS }\end{array}$ & $\begin{array}{l}\text { Levers of control framework } \\
\text { (Simons 1995) }\end{array}$ \\
\hline Cardinal (2001) & $\begin{array}{l}\text { Behavior control, input } \\
\text { control, output control }\end{array}$ & $\begin{array}{l}\text { Contingency approach } \\
\text { (Dewar and Dutton 1986, } \\
\text { Duncan 1976, Keller 1994) }\end{array}$ \\
\hline Davila (2000) & Design of MCS, use of MCS & $\begin{array}{l}\text { Concept of uncertainty } \\
\text { (Galbraith 1973) }\end{array}$ \\
\hline Jørgensen and Messner (2009) & $\begin{array}{l}\text { Enabling and constraining } \\
\text { MCS }\end{array}$ & $\begin{array}{l}\text { Concepts of coercive and } \\
\text { enabling forms of } \\
\text { bureaucracy (Adler and } \\
\text { Borys 1996) }\end{array}$ \\
\hline Pfister (2014) & $\begin{array}{l}\text { Diagnostic use of MCS, } \\
\text { interactive use of MCS }\end{array}$ & $\begin{array}{l}\text { Levers of control framework } \\
\quad \text { (Simons 1995) }\end{array}$ \\
\hline Richtnér and Åhlström (2010) & $\begin{array}{l}\text { Formal control, informal } \\
\text { control }\end{array}$ & $\begin{array}{l}\text { SECI-model for } \\
\text { organizational knowledge } \\
\text { creation (Nonaka 1994); } \\
\text { contingency approach } \\
\text { (Becerra-Fernandez and } \\
\text { Sabherwal 2001) }\end{array}$ \\
\hline Westling (2002) & $\begin{array}{l}\text { Formal use of MCS, informal } \\
\text { use of MCS }\end{array}$ & $\begin{array}{l}\text { Loose coupling approach } \\
\text { (Orton and Weick 1999) }\end{array}$ \\
\hline
\end{tabular}

in regards to innovation metrics that the "findings not only show the importance of the relationship between the design of innovation metrics and their conceptual use, but also underline the value of empirically validating the design factors of formal performance management systems within product innovation" (Janssen et al. 2011, 109). This is an important point to consider that the design mode as well as the use mode of MCS matter in the context of innovation. The challenge of research in the field of management control and innovation becomes now obvious. It lies in the analysis of both structure (determinism) and action (voluntarism) as well as micro- (individual) and macro-focused (organizational) analysis without giving primacy to either.

Categorization 3: Enabling and constraining character of MCS in the context of innovation

As shown in Table 3, two Cat1 studies (Cardinal 2001; Richtnér and Åhlström 2010) and five Cat2 studies (Bisbe and Malagueño 2009; Bisbe and Otley 2004; Davila 2000; Pfister 2014; Westling 2002) can additionally be classified as being part of categorization 3 (Cat3). The article by Jørgensen and Messner (2009) is the only empirical study listed in Table 3 which was neither part of the Cat 1 nor Cat 2 studies.

Cat 3 studies encompass the distinction between the enabling and constraining characteristics of MCS. On the one hand, Cat3 studies sort the existing literature according to the contributing as well as counterproductive role of MCS in the context of innova- 
tion. Usually, a traditional view is thereby introduced which "mainly characterize[s] MCS as hindering or, at most, being irrelevant in R\&D settings" (Davila 2000, 384; cf. Bisbe and Otley 2004). In contrast to the traditional view, it is stated that a "growing number of studies have concluded that formal MACS [management accounting and control systems] may effectively contribute to the innovation effort" (Bisbe and Malagueño 2009, 371f.; cf. Bisbe and Otley 2004; Pfister 2014). Consequently, controlling of innovation in organizations is not seen any more as a paradox but as a necessity to balance the tension between efficiency and effectiveness. Likewise, managerial control can thereby enable or constrain.

Those Cat 3 studies which are Cat 1 studies likewise explain the enabling or constraining character of MCS based on the belief that MCS directly shape behavior in a certain way (Cardinal 2001; Richtnér and Åhlström 2010). Thus, the enabling or constraining character of a MCS mainly depends on its ideal fit. There are MCS and related elements which seem to be appropriate or inappropriate for the context of innovation. Conversely, those Cat 3 which are Cat 2 studies likewise may instead argue that "under some styles of use, formal MACS may be dynamic, flexible and adaptive to changing environments, whilst at the same time being stable enough to frame cognitive models and communication patterns" (Bisbe and Malagueño 2009, 372). Cat2 studies accept from a voluntarist perspective that humans influence as well as change the organizational effects of a MCS. Thus, human beings with different interests, knowledge and opportunities are responsible for the enabling or constraining character of a certain MCS in the context of innovation.

In Cat 3 studies, so far the constraining or enabling effects of managerial control are mainly investigated in settings which are seen as innovative per se. Mainly, product development professionals, $\mathrm{R} \& \mathrm{D}$ directors, $\mathrm{R} \& \mathrm{D}$ project leaders in high-tech companies and innovation managers are asked to respond to surveys or are interviewed and observed in their daily routine. Yet, there is little research on how the same MCS is enacted in innovative contexts compared to non-innovative contexts. Research designs of this kind can open potential to understand the impact of the design of MCS in different contexts.

Furthermore, it is not entirely clear yet what empirical studies in management control and innovation try to achieve regarding the complexity and uncertainty of innovation processes. Complexity and uncertainty are by definition constitutional for innovation processes. However, it seems complexity and uncertainty shall be either reduced by identifying the ideal contingency fit or, on the contrary, MCS shall harness uncertainty and complexity of the innovation process as such.

Given the bounded rationality of human cognition, the handling of uncertainty and complexity becomes an essential question and needs to result in novel research questions for management control in the context of innovation. It begins by taking serious that no universal solutions to problems of control in the context of innovation are possible and may end by understanding the contingency perspective of organizations as a search for 'quasi fits' (Donaldson 2001, Volberda et al. 2012) of MCS in the context of innovation. The 'quasi fit' understanding of MCS takes into account that a control system in the context of innovation can never be a perfect solution in all situations at all times. They achieve their functionality not before practice, they are enacted and adapted there and undergo at best continuous modification to suit innovat- 
ing activities - taking into account that a once assumed ideal fit of MCS for a certain task environment at a certain point in time can be prejudicial in the future. Jørgensen and Messner (2009) deliver an example and report from repair efforts (Adler and Borys 1996) of engineers in a company for automated analytical solutions to adjust management control systems to their needs, to understand the origin of production costs, to satisfy top managers' expectations and finally to make a good case for their products. The example illustrates an implication of a 'quasi fit' understanding of MCS: it could fix MCS failures or to intervene if misuse of MCS becomes apparent.

The following section grasps at the implications for future research based on the marked and unmarked states of the three categorizations and based on the insights from the suggested 'quasi-fit' interpretation of contingency presented above.

\section{An agenda for research in management control and innovation}

The 'quasi fit' agenda for research on management control in the context of innovation suggests to become firstly more informed by the current discourses about an evolutionary understanding of innovation processes. Secondly, in order to understand MCS as dependent as much as independent variable scholars in management control can become inspired from an analogue discourse in technology research (for a current overview see Leonardi and Barley 2010). Finally, accounting research can deliver useful insights in economizing innovative activities and the way organizations cope with the economic contingencies in the context of innovation.

\section{Evolutionary perspective on innovation and management control}

The evolutionary perspective (Dosi 1982; Nelson and Winter 1982) describes innovation processes as processes of variation (emergence of novelty), selection (excluding unfit novelties) and retention (elaboration of the remaining novelties). In doing so, innovation processes unfold under uncertainty but they are neither ordered nor randomly accomplished processes. They are non-routine tasks. Non-routine tasks can be defined as tasks with low task analyzability (absence of well-established techniques for performing tasks) and a high number of exceptions (high degree of variety in the tasks encountered) (Abernethy and Brownell 1997, cf. Perrow 1970). Innovation processes are experienced as complex. Complexity derives from evolutionary complexity, relational complexity, temporal complexity and cultural complexity (Garud et al. 2013). Evolutionary complexity emerges from a path dependent sequence of events shaping invention, development and implementation. Relational complexity results from "entanglement and interaction between social and material elements (...). Changes in any part of an innovation impact some other part in an interactive manner" (Garud et al. 2013, 795). Temporal complexity describes the fact that actors engaged in the innovation process face timely constrains differently. These actors ground their conception of the innovation process on varying experiences and temporal rhythms. Finally, cultural complexity explains that the definition of what is novel and useful depends on the cultural context. Each cultural context has its specific practices, values and discourses framing innovation. 
Managerial control has an inherent tendency to follow a "command-and control" rhetoric (Simons 1995, 3) and to retrieve uncertainties and complexities. In the context of innovation, however, it is challenged to appreciate "the diverse and contested nature of the organizational regime" (Hopwood 1983, 299). Managerial control needs to harness uncertainty and complexity for sustaining ongoing innovation while upholding the strategic and economic momentum of for-profit as well as of not-for-profit organizations. Thus, the context of innovation requires managerial control and related systems to handle the tension between order and disorder appropriately (Hopwood 1983). By enabling order and disorder in the context of innovation likewise, the immanent tensions must be balanced, for instance the tensions between top-down direction and bottom-up creativity (Simons 1995), between efficiency and performance (Hopwood 1983) or between exploitation, exploration and ambidexterity (Bedford 2015).

Facing the different kinds of complexities, in innovation research scholars "consider fragility and change as a baseline, and of interest to them is how closure and stability can be brought about" (Garud et al. 2013; Bijker et al. 1987). Similarly, it is one approach in management control to seek order and to develop continuously new managerial control instruments in order to retrieve uncertainties and complexities in innovation processes (e.g. Gleich and Schimank 2011). It is another one to appreciate "the diverse and contested nature of the organizational regime" (Hopwood 1983, 299) and to harness these complexities for sustaining ongoing innovation (Garud et al. 2013). The research field of management control in the context of innovation should address different kinds of complexity and what it is trying to achieve regarding the inherent tension between order and disorder. The community's attention thus should encompass various organization theories as already realized in management control outside the context of innovation (for instance Alcouffe et al. (2008) on actor-network theory; Baiman (1990) on principal-agent theory; Macintosh and Scapens (1990) on structuration theory; Power and Laughlin (1992) on critical management studies; Speklé (2001) on transaction cost economy).

\section{Management control systems as dependent and independent variable}

The 'quasi fit' agenda for research on management control in the context of innovation takes furthermore into consideration that MCS for innovation processes are a dependent and independent variable, likewise. Determinism understands innovating activities as caused by MCS. Thus, MCS exist independent of human behavior. They are analyzed as independent variable. Voluntarism, on the contrary, argues that humans can shape their environment and therefore make use of MCS. MCS are analyzed as dependent variable. As indicated by Janssen et al. (2011), an integration of the determinist and voluntarist perspective should be promoted since social and material factors of management control are equally important.

Technology researchers have been experiencing a related discussion swinging between technological determinism and social constructivism since the 1980s (Leonardi and Barley 2010). Depending on the period of research, the role of technology was either downplayed and the social construction process became focus of attention and with it themes like social influence, work practices and role relations. Or, deterministic perspectives emphasized the technical over the social, framing technology as trigger for change and organizational structure (Leonardi and Barley 2010). As 
recommended by Leonardi and Barley for technology research, research in management control in the context of innovation similarly disentangles design and use aspects of MCS. However, since the human and social factors are equally important as MCS, it becomes necessary to figure out precisely what innovation enables or constrains - the use of MCS by human beings or the design of MCS as such.

Without doubt, it is challenging to extract the relative contributions of the design and of the use and to attribute their specific impact on innovation. There are two suggestions to start disentangling the respective contribution. As Leonardi and Barley already suggest for technology research, empirical investigations could equally focus on the implementation of MCS in the context of innovation. Implementations of MCS can be empirically insightful since they mark "a time when an existing sociomaterial fabric is disturbed, offering researchers an opportunity to 'see' more clearly how the social and the material become constitutively entangled" (Leonardi and Barley 2010, 34). Further longitudinal studies can enable researchers to find out "under what conditions the material or the social have the upper hand" (Leonardi and Barley 2010, 35). Compared to cross-sectional studies longitudinal studies go beyond an investigation of a single moment in time and can track implementation processes of various organizations. Differences observed in those implementation processes in the long-term are less likely to be the result of organizational differences but due to the implemented MCS. Moreover, it can be reasonable to have a look at different analytical levels like individuals, groups, communities or organizations and their MCS usage. Variations in MCS usage may decrease on higher analytical levels so that an opportunity is created to disentangle the social and the material forces of management control. After all, a better knowledge of the impact of material forces can provide an elaborated basis for the prospective development of MCS in the context of innovation on the one hand. On the other hand, the occurrence of MCS repair efforts of employees (Jørgensen and Messner 2009) or the incidence of deviant behavior ignoring requirements from formal MCS can be an expression of how organizational members cope with contingencies in innovating activities. These phenomena need to be investigated further to elaborate on the 'quasi fit' of MCS in the context of innovation.

\section{Understanding the relation between innovating and economizing}

As a third direction of research for management control and innovation, the article suggests to investigate the interrelatedness of innovating and economizing processes. As the definition postulates, MCS inscribe a strategic as well as economic momentum on innovating activities. MCS do not simply "inform economic decision-making, but in many cases [they] constitute the domain of economic activity itself" (Miller and Power 2013,579). Hence, a R\&D department of a company is turned into an economic entity for which the tension between efficiency and effectiveness becomes consequently constitutive. A similar discourse can be found, for instance in the debate on 'new public management' for universities and hospitals. In the context of both for-profit and notfor-profit organizations, the process of invention, development and implementation of new ideas is a profoundly economic process.

In the field of accounting research, Miller and Power call this transformation a process of economization. In this process, accounting techniques constitute the domain of economic activity in four ways by territorializing, mediating, adjudicating and 
subjectivizing. First, accounting techniques territorialize. They construct recursively "calculable spaces that actors inhabit within organizations" (Miller and Power 2013, 557). These calculable spaces allow that performance can be reviewed, evaluated and compared within as well as among organizations (Miller and Power 2013). Second, they are used to mediate. In an ongoing process, accounting techniques connect different actors and provide a common language among actors on the side of the organization and beyond its boundaries. Third, adjudicating takes place if accounting techniques are used to evaluate performance and to detect failings and failures. Finally, accounting is framed as "subjectivizing practice par excellence, that it both subjects individuals to control or regulation by another, while entailing the presumption of an individual free to choose" (Miller and Power 2013, 557). In the process of economization, actors with multiple logics compete for priority and search for spaces to exercise a certain kind of economic freedom.

Interestingly, the four ways how accounting constitutes the domain of economic activity could be utilized in the field of management control and innovation. Territorializing, mediating, adjudicating and subjectivizing can be understood as economic activities to cope with contingencies of the context of innovation. Hence, prospective research could shed light on the question what is in fact interactively or diagnostically communicated and negotiated and what moderating and mediating precisely mean in MCS usage (e.g. Bisbe and Otley 2004). Adequately, scholars could ask how MCS create calculable spaces by distributing responsibility and framing accountability in innovation processes (territorializing). Furthermore, it could be of interest how MCS provide a common language and relate different, sometimes conflicting interests of actors regarding efficiency and effectiveness (mediating). Research questions asking, for example, who is held accountable for innovation performance, what is measured and evaluated in R\&D projects, or how failings and failures are detected in practice, can contribute to gain further rich insights into the nature of management control in the context of innovation (adjudicating). In turn, investigating the ways in which innovating actors search for spaces to gain a certain kind of creative as well as economic freedom could highlight the diversity of behavioral responses on MCS usage in innovation processes (subjectivizing).

\section{Conclusion}

The article reviewed twenty-five empirical studies to analyze and assess the current state of research on management control in the context of innovation. By critically reflecting on the chosen control distinctions and underlying interpretations of the contingency, the 'quasi fit' agenda of management control and innovation was developed.

This article aimed to respond to two research questions. The first question asked about the achievements and limitations in studying MCS in the context of innovation empirically. The current empirical studies refer to three main control distinctions represented by three categorizations: the types of managerial control (Cat1 studies), the design and use mode of managerial control instruments (Cat2 studies), and finally the enabling and constraining character of managerial control instruments (Cat3 studies). By assessing these categorizations, it became evident that there are two, almost independent ontological streams shaping the empirical field: the determinist perspective 
and the voluntarist perspective of management control with differing understandings of contingency and informed either by the 'ideal fit' interpretation or the 'quasi fit' interpretation of contingency.

As stated in the introduction, current findings in the field of management control and innovation are often inconclusive and produce rarely cumulative knowledge. The article identified the 'ideal fit' interpretation of contingency as one substantial reason for it assuming the research agenda of management control and innovation is associated with the identification and matching of specific MCS elements or packages to specific circumstances (contingency factors).

Therefore, the article suggested alternatively to further strengthen the 'quasi fit' interpretation of contingency. The 'quasi fit' understanding highlights the original interpretation of contingency that a control system in the context of innovation can never be a perfect solution in all situations at all times. Consequently, other research questions need to be addressed disentangling the social and the material forces of management control on the one hand and evaluating on the other hand deviant and repair behavior related to MCS in organizations to cope with contingencies in innovating activities.

The second question placed an emphasis on how the innovation agenda in management control should be advanced in the future. Based on the present empirical findings and informed by the current discourse and achievements of innovation research, technology research and accounting research, three missions are suggested to be put on the future 'quasi fit' agenda for research on management control and innovation: (1) to connect to an evolutionary understanding of innovation processes, (2) to understand management control systems as dependent as much as independent variable and (3) to explore the role of MCS in economizing innovative activities.

A 'quasi fit' agenda for management control in the context of innovation has also practical implications. For organizations this agenda claims to take assessments of different organizational members regarding MCS in the context of innovation serious, to learn from and to understand what deviant or repair behavior causes. In the end, organizations need to decide pro-actively to what extent organizational members involved in innovating activities (in essence being non-experts in management control) shall be assigned and empowered to adapt MCS according to their (changing) needs in the course of time.

Acknowledgements I wish to express my gratitude to the three anonymous reviewers and to the managing editor Professor Thomas Guenther for their very helpful comments and guidance.

Open Access This article is distributed under the terms of the Creative Commons Attribution 4.0 International License (http://creativecommons.org/licenses/by/4.0/), which permits unrestricted use, distribution, and reproduction in any medium, provided you give appropriate credit to the original author(s) and the source, provide a link to the Creative Commons license, and indicate if changes were made.

\section{Appendix 1}

See Table 4. 
Table 4 Overview of academic journals where the systematic database search revealed results (before the study sample was deducted from)

\section{Accounting Horizons}

Accounting Review

Accounting, Auditing \& Accountability Journal

Accounting, Organizations \& Society

Asia Pacific Journal of Management

Asian Review of Accounting

Brazilian Business Review (English edition)

British Accounting Review

British Journal of Management

Chartered Accountants Journal

Construction Management \& Economics

Critical Perspectives on Accounting

Electronic Journal of Knowledge Management

Employee Relations

European Accounting review

European Journal of Innovation Management

Financial Management

Foundations \& Trends in Accounting

Industrial Relations Journal

International Journal of Accounting Information Systems

International Journal of Engineering Business Management

International Journal of Human Resource Management

International Journal of Innovation \& Technology Management

International Journal of Innovation Management

International Journal of Innovation Science

International Journal of Operations \& Production Management

International Journal of Organizational Innovation

International Journal of Production Research

International Journal of Project Management

International Journal of Services Technology \& Management

International Journal of Technology Management

Journal of Business \& Retail Management Research

Journal of Business Ethics

Journal of Corporate Accounting \& Finance (wiley)

Journal of Intellectual Capital

Journal of International Management Studies

Journal of Management Accounting Research

Journal of Management Control

Journal of Management Studies

Journal of Product Innovation Management 
Table 4 continued

Lex Et Scientia International Journal

Long Range Planning

Management Accounting Research

Measuring Business Excellence

Qualitative Research in Accounting \& Management

R\&D management

strategic finance

The International Journal of Human Resource Management

Theoretical Journal of Accounting (zeszyty teoretyczne rachunkowosci)

\section{Appendix 2}

See Table 5. 


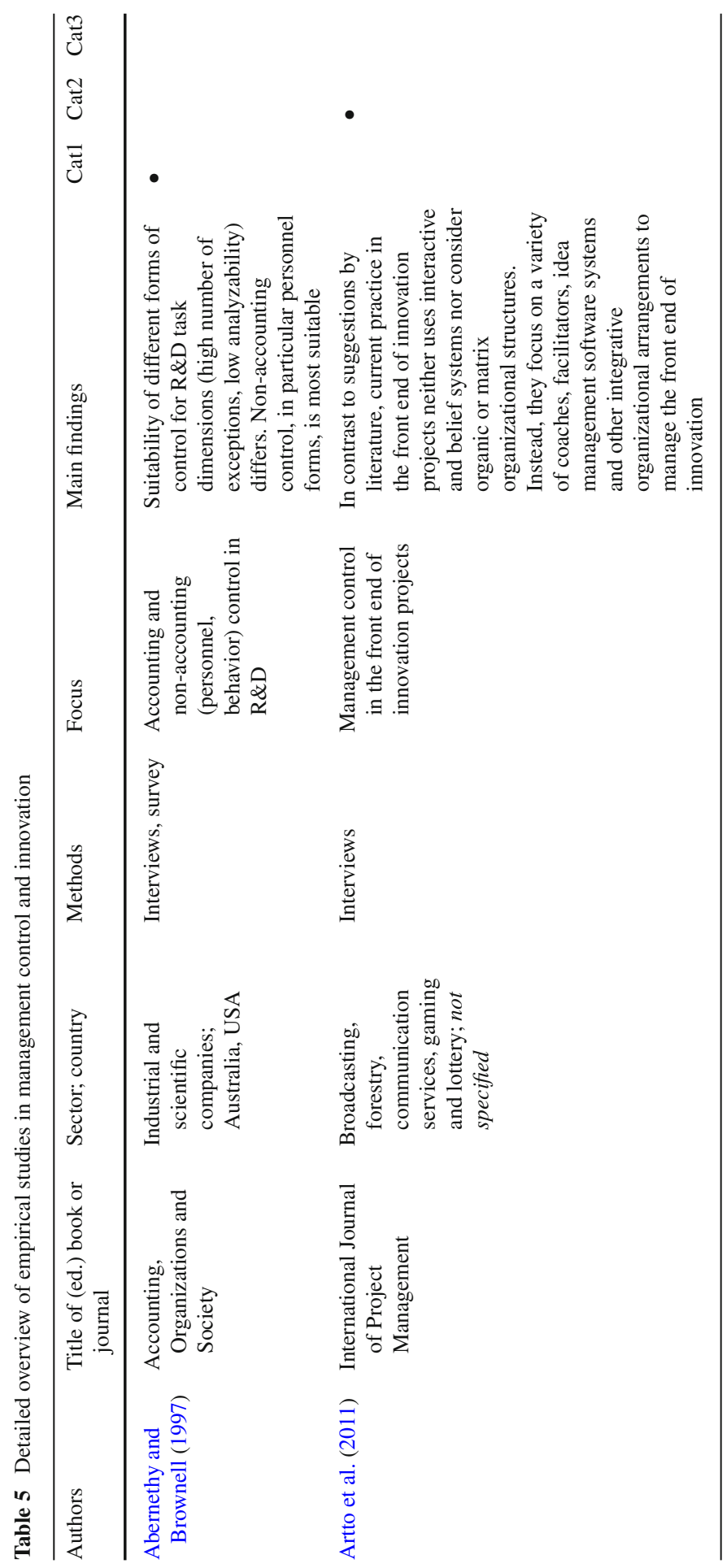




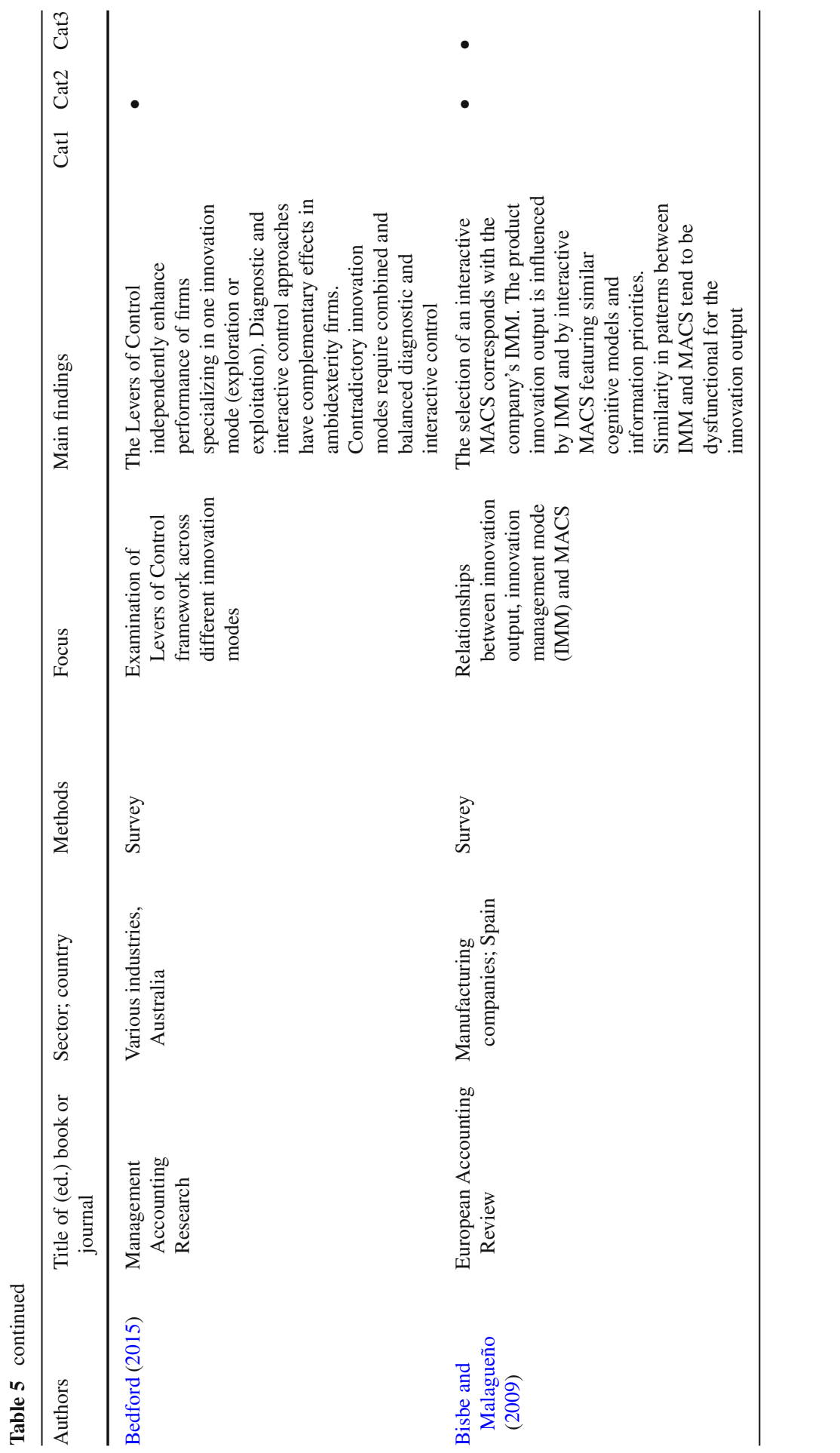




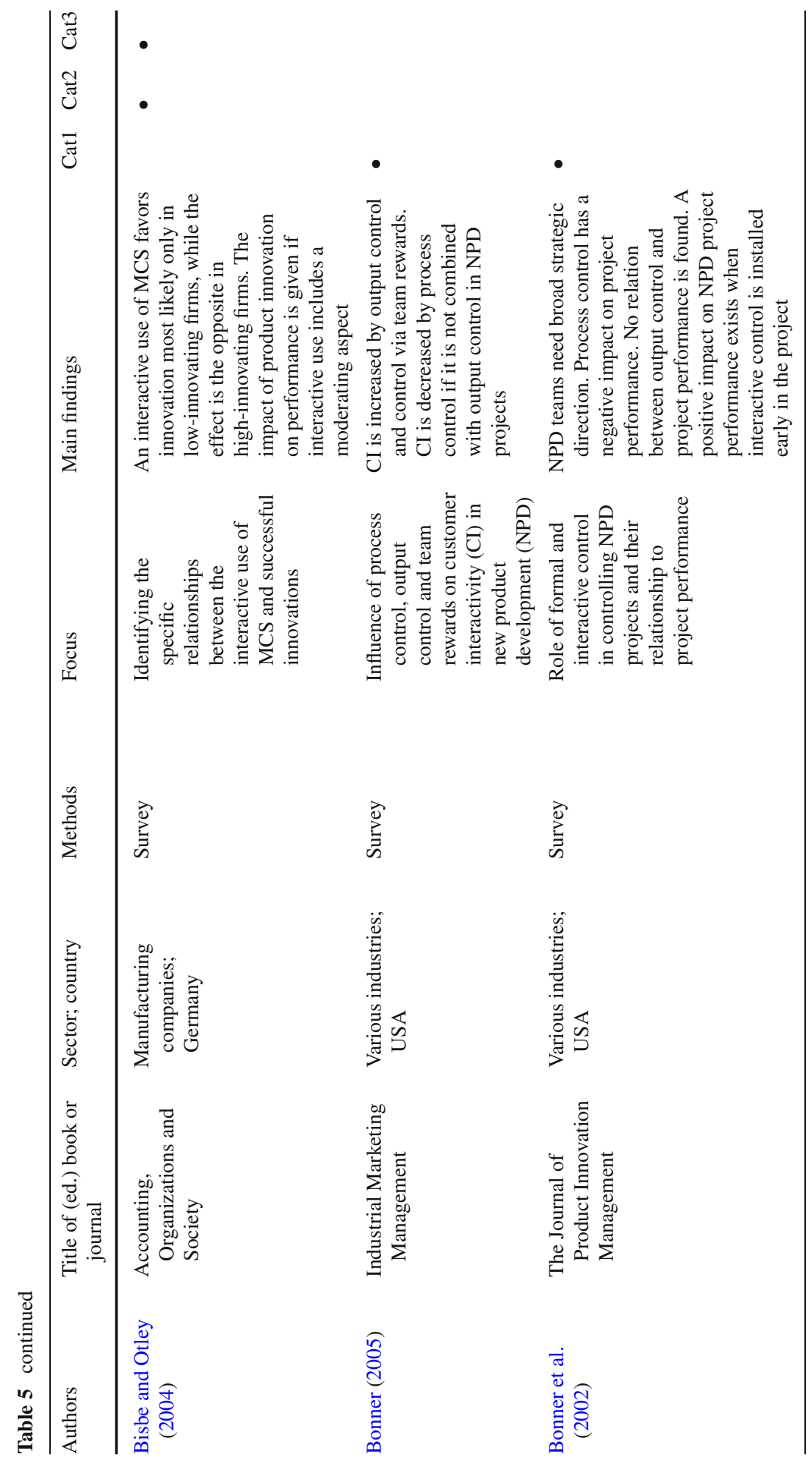




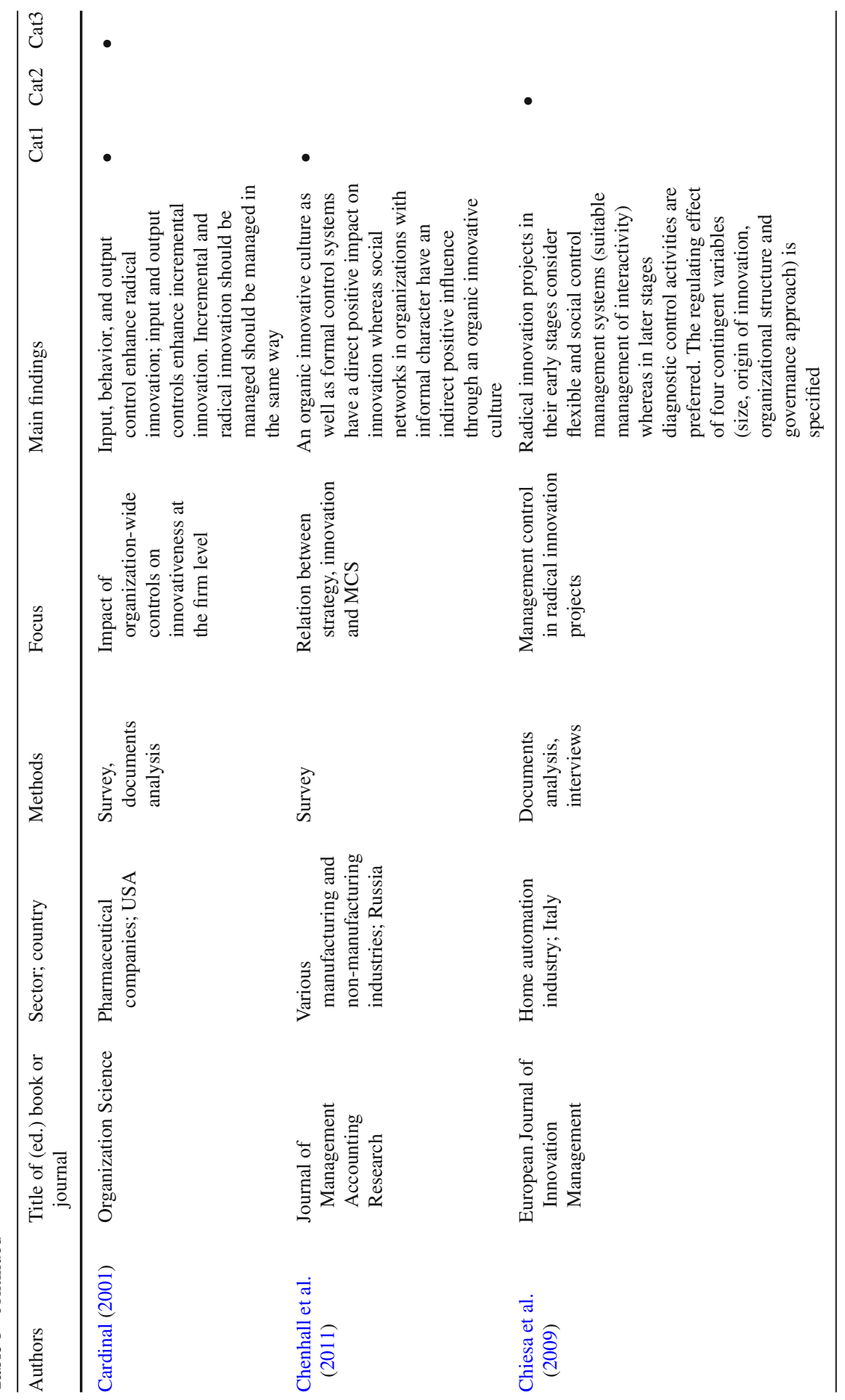




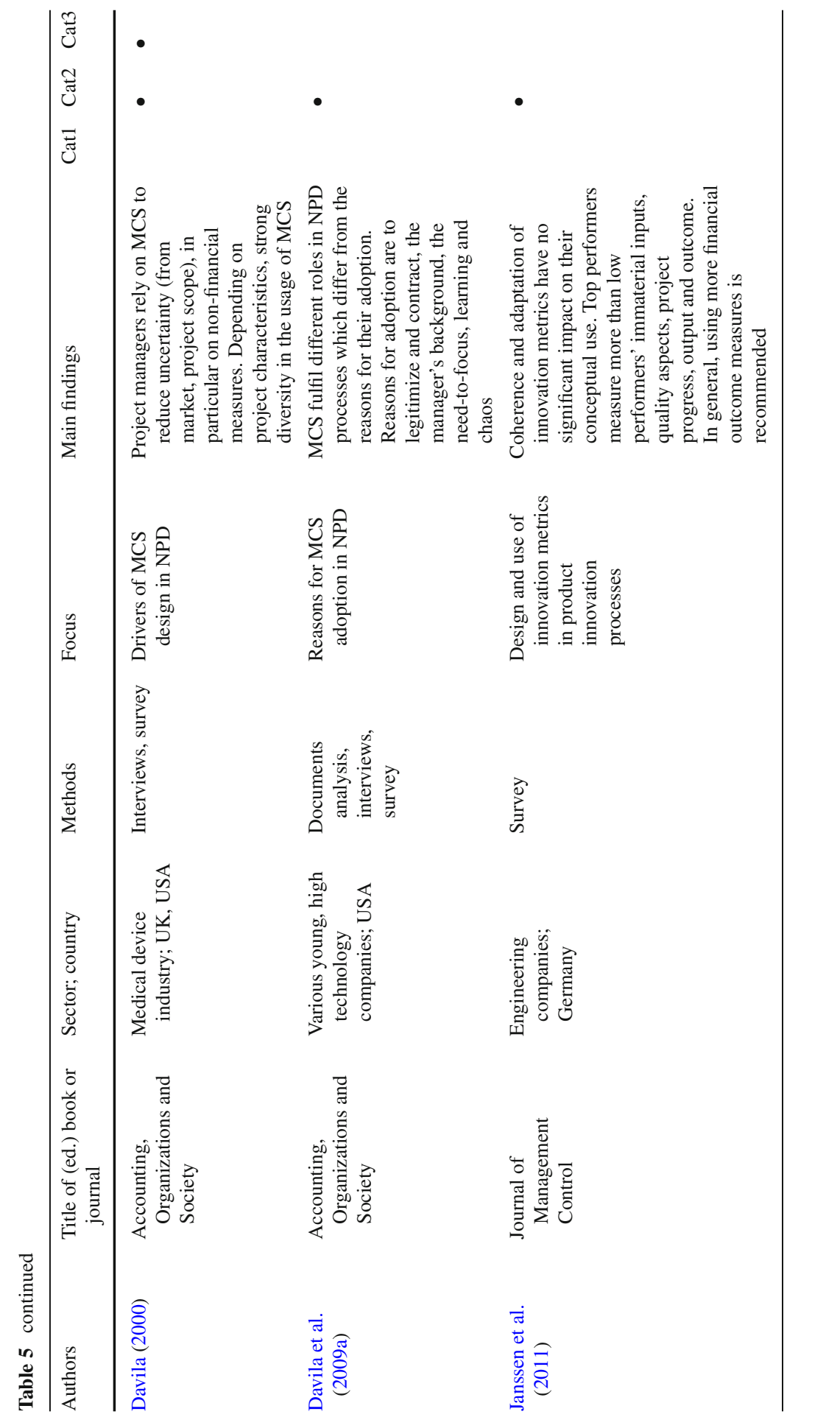




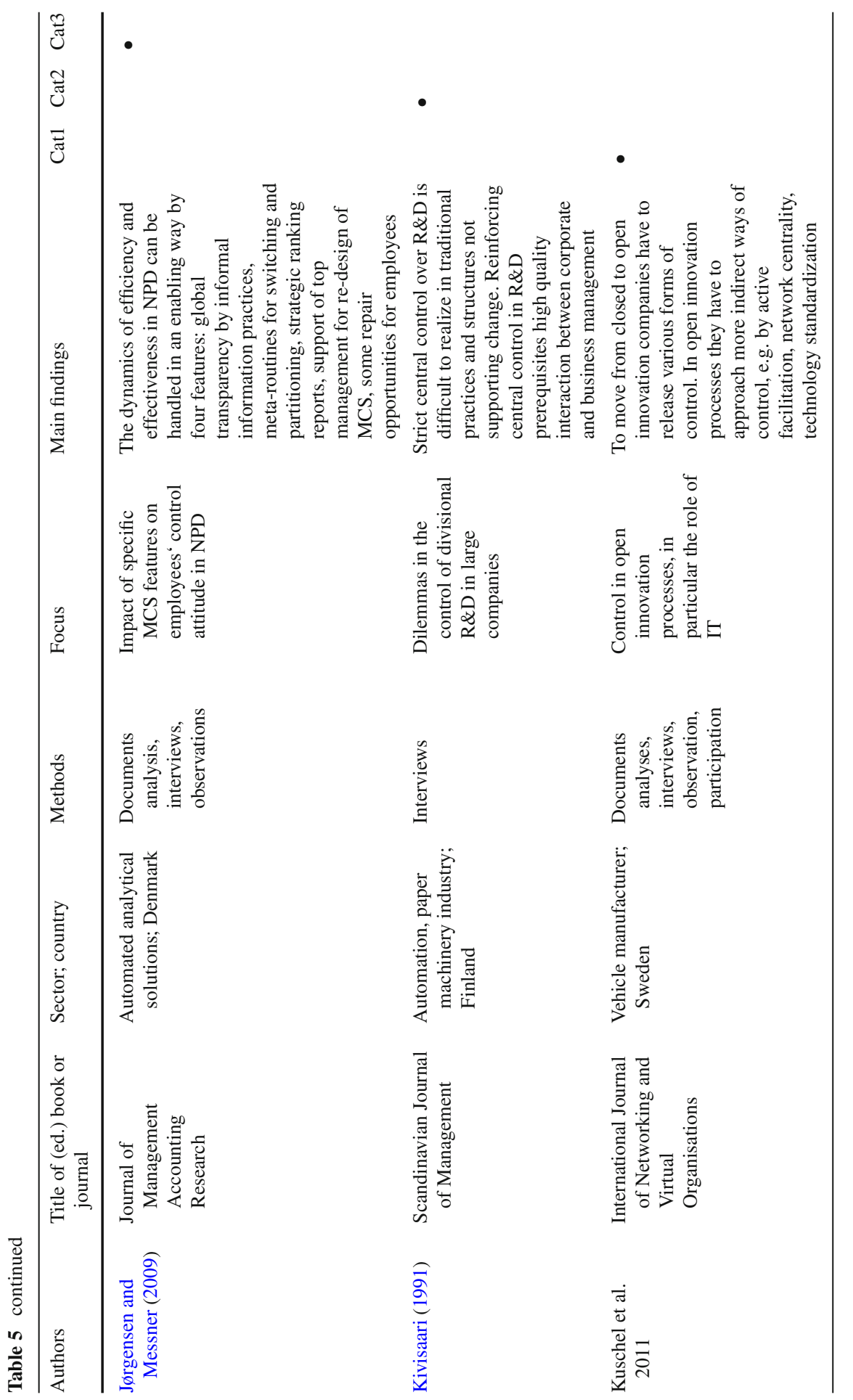




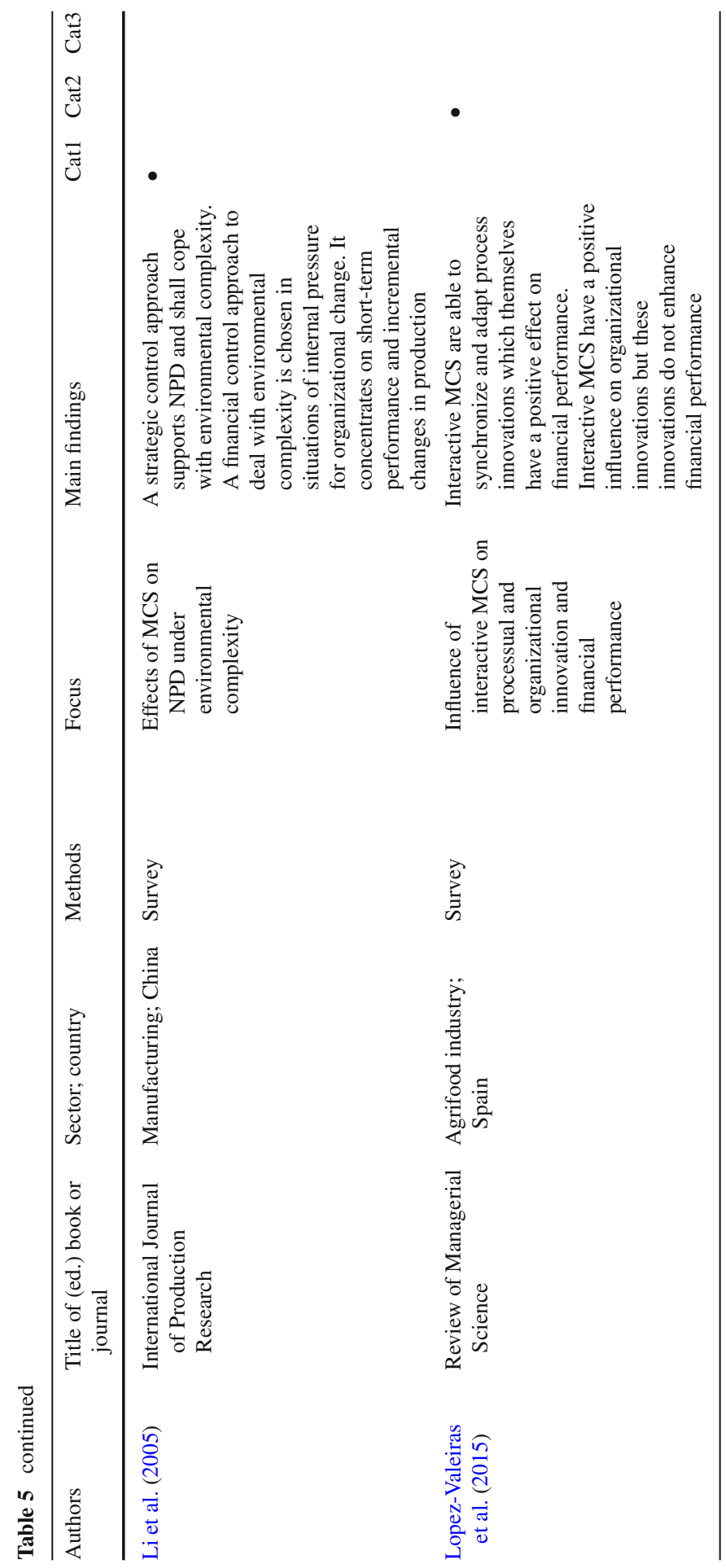




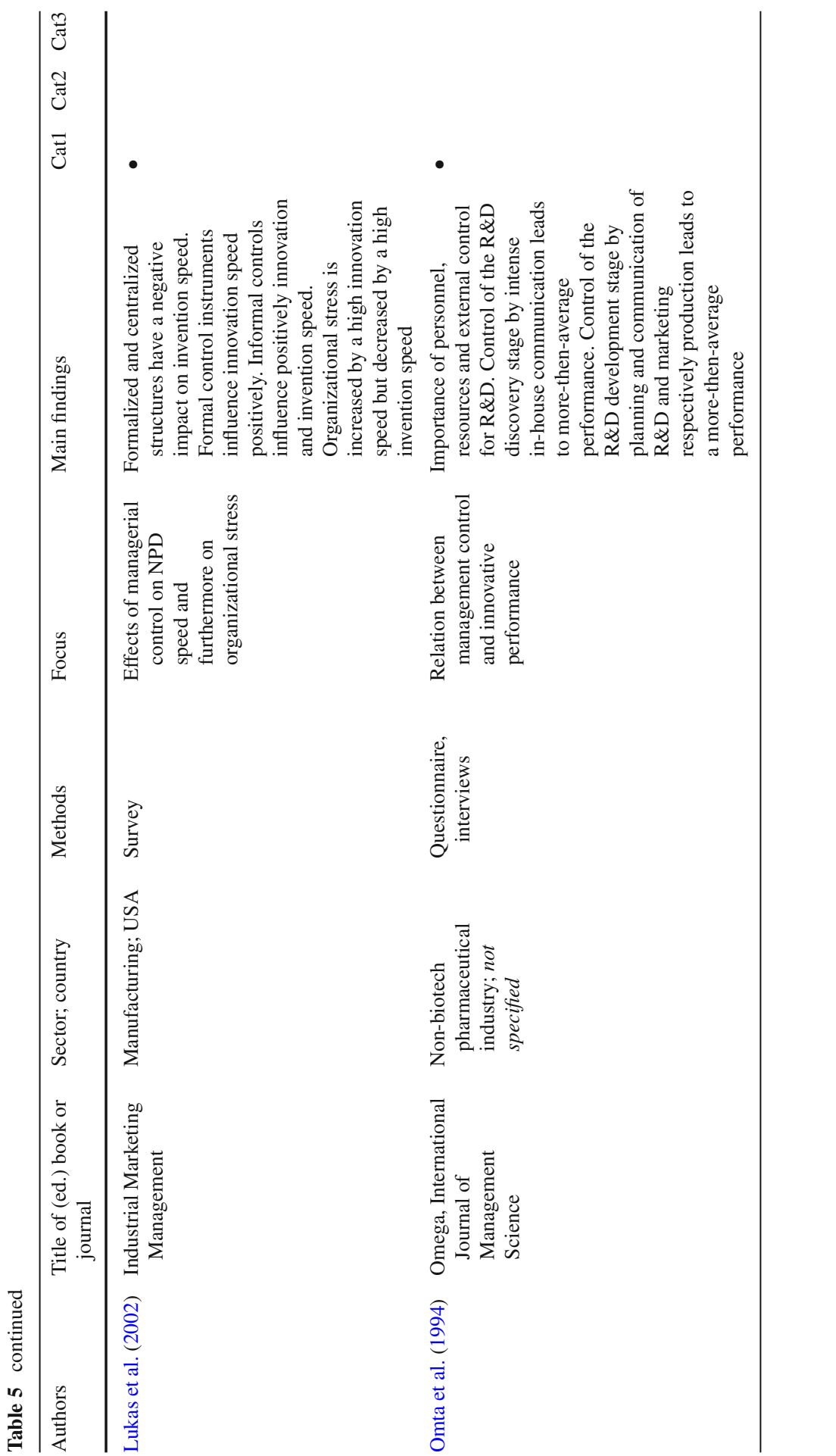




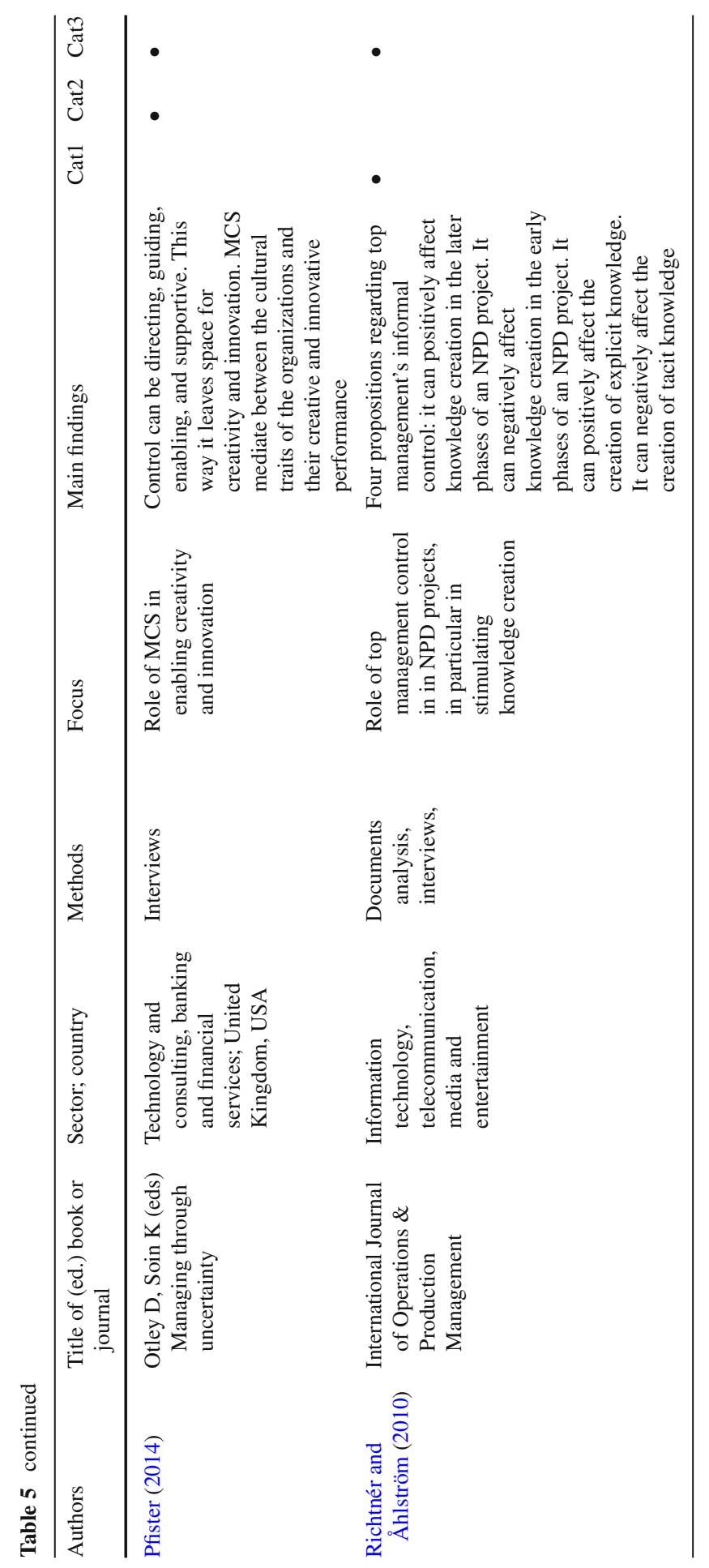




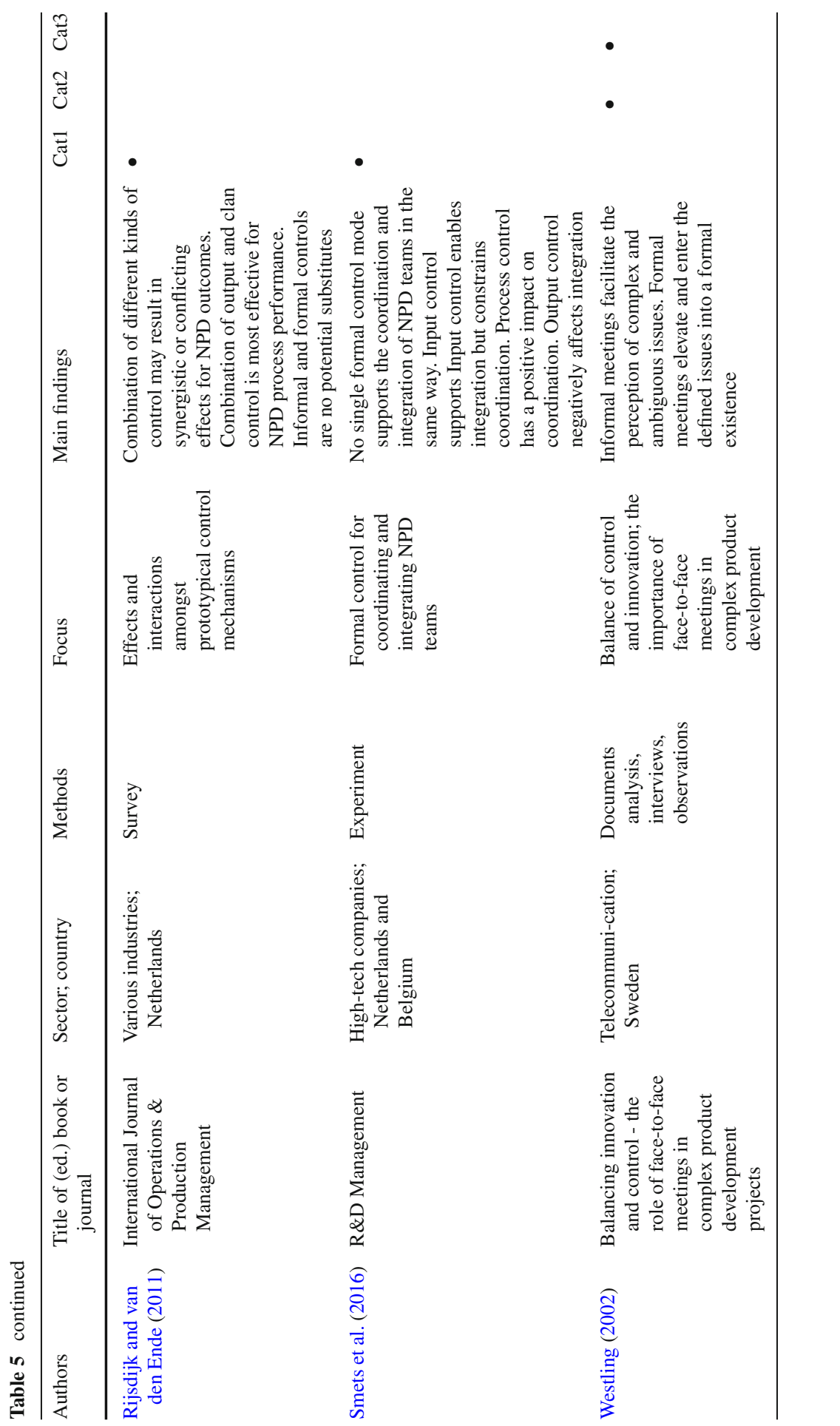




\section{References}

Abernethy, M. A., \& Brownell, P. (1997). Management control systems in research and development organizations: The role of accounting, behavior and personnel controls. Accounting, Organizations and Society, 22, 233-248*

Adler, P. S., \& Borys, B. (1996). Two types of bureaucracy: Enabling and coercive. Administrative Science Quarterly, 41, 61-89.

Adler, P. S., \& Chen, C. X. (2011). Combining creativity and control: Understanding individual motivation in large-scale collaborative creativity. Accounting, Organizations and Society, 36, 63-85.

Alcouffe, S., Berland, N., \& Levant, Y. (2008). Actor-networks and the diffusion of management accounting innovations: A comparative study. Management Accounting Research, 19, 1-19.

Alvesson, M., \& Kärreman, D. (2004). Interfaces of control: Technocratic and socio-ideological control in a global management consultancy firm. Accounting, Organizations and Society, 29, 423-444.

Amabile, T. M. (1998). How to kill creativity. Harvard Business Review, 76, 76-87.

Argyris, C. (1972). The applicability of organizational sociology. Cambridge: Cambridge University Press.

Artto, K., Kulvik, I., Poskela, J., \& Turkulainen, V. (2011). The integrative role of the project management office in the front end of innovation. International Journal of Project Management, 29, 408-421*

Baiman, S. (1990). Agency research in managerial accounting: A second look. Accounting, Organizations and Society, 15, 341-371.

Becerra-Fernandez, I. \& Sabherwal, R. (2001). Organizational knowledge management: a contigency perspective. Journal of Information Systems, 18(1), 23-55.

Bedford, D. S. (2015). Management control systems across different modes of innovation: Implications for firm performance. Management Accounting Research, 28, 12-30*

Berry, A. J., Coad, A. F., Harris, E. P., Otley, D. T., \& Stringer, C. (2009). Emerging themes in management control: A review of recent literature. The British Accounting Review, 41, 2-20.

Bijker, W. E., Hughes, T. P., \& Pinch, T. J. (Eds.). (1987). The social construction of technological systems: New directions in the sociology and history of technology. Cambridge, MA: MIT Press.

Bisbe, J., \& Malagueño, R. (2009). The choice of interactive control systems under different innovation management modes. European Accounting Review, 18, 371-405*

Bisbe, J., \& Otley, D. (2004). The effects of the interactive use of management control systems on product innovation. Accounting, Organizations and Society, 29, 709-737*

Bonner, J. M. (2005). The influence of formal controls on customer interactivity in new product development. Industrial Marketing Management, 34, 63-69*

Bonner, J. M., Ruekert, R. W., Walker, J., \& Orville, C. (2002). Upper management control of new product development projects and project performance. The Journal of Product Innovation Management, 19, 233-245*

Bourne, M. (2014). Managing through uncertainty. In D. T. Otley \& K. Soin (Eds.), Management control and uncertainty (pp. 97-113). London: Palgrave Macmillan.

Breunig, K. J., Aas, T. H., \& Hydle, K. M. (2014). Incentives and performance measures for open innovation practices. Measuring Business Excellence, 18, 45-54.

Burns, T., \& Stalker, G. M. (1961). The management of innovation. London: Tavistock.

Bruns, W. J., \& DeCoster, D. T. (1969). Accounting and its behavioral implications. McGraw-Hill:New York.

Cardinal, L. B. (2001). Technological innovation in the pharmaceutical industry: The use of organizational control in managing research and development. Organization Science, 12, 19-36*

Chapman, C. S. (1997). Reflections on a contingent view of accounting. Accounting, Organizations and Society, 22, 189-205.

Chenhall, R. H. (2003). Management control systems design within its organizational context: Findings from contingency-based research and directions for the future. Accounting, Organizations and Society, $28,127-168$.

Chenhall, R. H., Kallunki, J.-P., \& Silvola, H. (2011). Exploring the relationships between strategy, innovation, and management control systems: The roles of social networking, organic innovative culture, and formal controls. Journal of Management Accounting Research 23, 99-128*

Chenhall, R. H., \& Moers, F. (2015). The role of innovation in the evolution of management accounting and its integration into management control Accounting. Organizations and Society, 47, 1-13.

Chiesa, V., Frattini, F., Lamberti, L., \& Noci, G. (2009). Exploring management control in radical innovation projects. European Journal of Innovation Management, 12, 416* 
Child, J. (1972). Organizational structure, environment and performance: The role of strategic choice. Sociology, 6, 1-22.

Collins, M. A., \& Amabile, T. M. (1999). Motivation and creativity. In R. J. Sternberg (Ed.), Handbook of creativity (pp. 297-312). Cambridge: Cambridge University Press.

Cowton, C. J., \& Dopson, S. (2002). Foucault's prison? Management control in an automotive distributor. Management Accounting Research, 13, 191-213.

Davila, A., Foster, G., \& Li, M. (2009a). Reasons for management control systems adoption: insights from product development systems choice by early-stage entrepreneurial companies. Accounting, Organizations and Society, 34, 322-347*

Davila, A., Foster, G., \& Oyon, D. (2009b). Accounting and control, entrepreneurship and innovation: Venturing into new research opportunities. European Accounting Review, 18, 281-311.

Davila, T. (2000). An empirical study on the drivers of management control systems' design in new product development. Accounting, Organizations and Society, 25, 383-409*

Dosi, G. (1982). Technological paradigms and technological trajectories: A suggested interpretation of the determinants and directions of technical change. Research Policy, 11, 147-162.

Donaldson, L. (2001). The contingency theory of organizations. Thousand Oaks, CA: Sage.

Dewar, R. D., \& Dutton, J. E. (1986). The adoption of radical and incre- mental innovations: An empirical analysis. Management Science, 32, 1422-1433.

Duncan, R. (1976). The ambidextrous organization: Designing dual structures for innovation. R. H. Kilmann, L. R. Pondy, D. P. Slevin, (Eds.). The Management of Organization Design, Vol. 1, North-Holland, New York, 167-188.

Ferreira, A., Moulang, C., \& Hendro, B. (2010). Environmental management accounting and innovation: An exploratory analysis. Accounting, Auditing \& Accountability Journal, 23, 920-948.

Fried, A. (2010). Performance measurement systems and their relation to strategic learning: A case study in a software developing organization. Critical Perspectives on Accounting, 21, 118-133.

Fried, A., Gey, R., Pretorius, A., \& Günther, L. (2013). Decoupling from standards-process management and technical innovation in software development organisations. International Journal of Innovation Management, 17, doi:10.1142/S1363919613500126.

Galbraith, J. (1973). Designing complex organizations. Addison-Wesley:Reading, MA.

Garud, R., Tuertscher, P., \& Van de Ven, A. (2013). Perspectives on innovation processes. The Academy of Management Annals, 7, 775-819.

Gavetti, G., Greve, H. R., Levinthal, D. A., \& Ocasio, W. (2012). The behavioral theory of the firm: Assessment and prospects. The Academy of Management Annals, 6, 1-40.

Gleich, R., \& Schimank, C. (Eds.). (2011). Innovations-Controlling. Freiburg: Haufe.

Goffman, E. (1963). Behavior in public places: Notes on the social organization of gatherings. New York: Free Press.

Goold, M. \& Campbell, A. (1988) Managing the diversified corporation: the tensions facing the chief executive. Long Range Planning, 21(4), 12-24.

Greiner, L. (1972). Evolution and revolution as organizations grow. Harvard Business Review, 50(4), 37-46.

Guenther, T. W. (2013). Conceptualisations of 'controlling' in German-speaking countries: Analysis and comparison with Anglo-American management control frameworks. Journal of Management Control, 23, 269-290.

Haustein, E., Luther, R., \& Schuster, P. (2014). Management control systems in innovation companies: A literature based framework. Journal of Management Control, 24, 343-382.

Hendry, C. (1979). Contingency theory in practice. Part I. Personnel Review, 8, 29-44.

Hewege, C. R. (2012). A critique of the mainstream management control theory and the way forward Sage Open. doi:10.1177/2158244012470114.

Hopwood, A. G. (1976). Accounting and human behavior. Englewood Cliffs: Prentice Hall.

Hopwood A.G. (1978) Towards an organizational perspective for the study of accounting and information systems. Accounting, Organizations and Society 3, 3-13.

Hopwood, A. G. (1983). On trying to study accounting in the context in which it operates. Accounting, Organizations, and Society 8, 287-305.

Ittner, C. D., \& Larcker, D. F. (1998). Innovations in performance measurement: Trends and research implications. Journal of Management Accounting Research, 10, 205-238.

Janssen, S., Moeller, K., \& Schlaefke, M. (2011). Using performance measures conceptually in innovation control. Journal of Management Control, 22, 107-128* 
Jørgensen, B., \& Messner, M. (2009). Management control in new product development: The dynamics of managing flexibility and efficiency. Journal of Management Accounting Research, 21, 99-124*

Kanter, M. R. (1983) The Change Masters. Basic Books: New York.

Kaplan, R. S. (2009). Conceptual foundations of the balanced scorecard. In C. Chapman, A. G. Hopwood, \& M. D. Shields (Eds.), Handbook of management accounting research (Vol. 3, pp. 1253-1269). Elsevier: Oxford.

Keller, R. T. (1994). Technology-information professing fit and the performance of R\&D project groups: A test of contingency theory. Academy of Management Journal, 37, 167-179.

Kivisaari, S. (1991). Management of innovation in the modern corporation: Dilemmas in the corporate control of R\&D. Scandinavian Journal of Management, 7, 219-228*

Kuschel, J., Remneland, B. \& Kuschel, M. H. (2011). Open innovation and control: A case from Volvo. International Journal of Networking and Virtual Organisations, 9,123-139*

Lawrence, P., \& Lorsch, J. (1967). Organization and environment. In: Harvard University Press. Boston, MA

Leonardi, P. M., \& Barley, S. R. (2010). What's under construction here? Social action, materiality, and power in constructivist studies of technology and organizing. The Academy of Management Annals, $4,1-51$.

Li, Y., Li, L., Liu, Y., \& Wang, L. (2005). Linking management control system with product development and process decisions to cope with environment complexity. International Journal of Production Research, $43,2577-2591 *$

Lopez-Valeiras, E., Gonzalez-Sanchez, M. B., \& Gomez-Conde, J. (2015). The effects of the interactive use of management control systems on process and organizational innovation. Review of Managerial Science, 24. doi:10.1007/s11846-015-0165-9.

Luhmann, N. (1984). Soziale Systeme. Frankfurt am Main

Luhmann, N. (1988). Frauen. Männer und George Spencer Brown Zeitschrift für Soziologie, 17, 47-71.

Lukas, B.A., Menon, A., Bell, S. J. (2002). Organizing for new product development speed and the implications for organizational stress. Industrial Marketing Management, 31, 349-355*

Macintosh, N. B., \& Scapens, R. W. (1990). Structuration theory in management accounting. Accounting, Organizations and Society, 15, 455-477.

Merchant, K. A., \& Van der Stede, W. A. (2012). Management control systems: Performance measurement, evaluation and incentives. Harlow: Pearson Education.

Miller, P., \& Power, M. (2013). Accounting, organizing, and economizing: Connecting accounting research and organization theory. The Academy of Management Annals, 7, 557-605.

Moll, J. (2015). Editorial: Special issue on innovation and product development. Management Accounting Research, 28, 2-11.

Möller, K., Menninger, J., \& Robers, D. (2011). Innovationscontrolling: Erfolgreiche Steuerung und Bewertung von Innovationen. Schäffer-Poeschel: Stuttgart.

Nelson, R. R., \& Winter, S. G. (1982). An evolutionary theory of economic change. Cambridge, MA: Belknap Press.

Nonaka, I. (1994). A dynamic theory of organizational knowledge creation. Organization Science, 5(1), 14-37.

Omta, S. W. F., Bouter, L. M., \& Van Engelen, J. M. L. (1994). Innovative and industrial performance in pharmaceutical R\&D, a management control perspective. Omega, 22,209-219*

Orton, D., \& Weick, K. (1990). Loosely Coupled Systems: A Reconceptualization. Academy of Management Review, 15(2), 203-223.

Otley, D. (1980). The contingency theory of management accounting and control: Achievement and prognosis. Accounting, Organization and Society, 5, 413-428.

Otley, D. (2016). The contingency theory of management accounting and control: 1980-2014. Management Accounting Research, 31, 45-62.

Ouchi, W. G. (1979). A conceptual framework for the design of organizational control mechanisms. Management Science, 25, 833-848.

Perrow, C. (1970). Organizational analysis: A sociological view. New York: Tavistock Publications.

Pfister, J. (2014). Controlling creativity and innovation: Paradox and necessity? In: D. Otley, \& K. Soin (Eds.), Managing through uncertainty (pp. 134-148). PalgraveMacmillan, London*

Power, M., \& Laughlin, R. (1992). Critical theory and accounting. In M. Alvesson \& H. Willmott (Eds.), Critical management studies (Vol. 1, pp. 113-135). London: Sage. 
Quattrone, P., \& Hopper, T. (2001). What does organizational change mean? Speculations on a taken for granted category. Management Accounting Research, 12, 403-435.

Randle, K., \& Rainnie, A. (1997). Managing creativity, maintaining control: A study in pharmaceutical research. Human Resource Management Journal, 7, 32-46.

Richtnér, A., \& Åhlström, P. (2010). Top management control and knowledge creation in new product development. International Journal of Operations \& Production Management, 30,1006-1031*

Rijsdijk, S. A., \& van den Ende, J. (2011). Control combinations in new product development projects. The Journal of Product Innovation Management, 28, 868-880*

Rosch, E. (1998). Principles of categorization. In G. Mather, F. Verstraten, \& S. M. Anstis (Eds.), The motion aftereffect: A modern perspective (pp. 251-270). Cambridge, MA: MIT Press.

Simon, H. (1991). Bounded rationality and organizational learning. Organization Science, 2, 125-134.

Simons, R. (1995). Levers of control. How managers use innovative control systems to drive strategic renewal. Boston, MA: Harvard Business School Press.

Smith, D., \& Nichol, R. T. (1981). Change, standardization and contingency theory. Journal of Management Studies, 18, 73-88.

Smets, L. P. M., Langerak, F., \& Tatikonda, M. V. (2016). Collaboration between competitors' NPD teams: In search of effective modes of management control. $R \& D$ Management, $46,244^{*}$

Speklé, R. F. (2001). Explaining management control structure variety: A transaction cost economics perspective. Accounting, Organizations and Society, 26, 419-441.

Spencer Brown, G. (1972). Laws of form. New York: The Julian Press.

Thompson, J. D. (2003). Organizations in action. Piscataway, NJ: Transaction Publishers.

Van de Ven, A. H., \& Drazin, R. (1985). The concept of fit in contingency theory. In B. W. Staw \& L. L. Cummings (Eds.), Research in organizational behavior (Vol. 7, pp. 333-365). JAI Press CT: Greenwich.

Volberda, H. W., van der Weerdt, N., Verwaal, E., Stienstra, M., \& Verdu, A. J. (2012). Contingency fit, institutional fit, and firm performance. Organization Science, 23, 1040-1054.

Weick, K. E., Sutcliffe, K. M., \& Obstfeld, D. (1999). Organizing for high reliability: Processes of collective mindfulness. In R. I. Sutton \& B. M. Staw (Eds.), Research in organizational behavior. JAI Press: Stamford.

Westling, G. (2002). Balancing innovation and control-The role of face-to-face meetings in complex product development projects. Handelshögskolan, Stockholm, https://ex.hhs.se/dissertations/ 221505-FULLTEXT01.pdf, download15February2015.*

Widener, S. K. (2007). An empirical analysis of the levers of control framework. Accounting, Organizations and Society, 32, 757-788.

Woodward, J. (1965). Industrial organization: Theory and practice. London: Oxford University Press.

Wright, P. M., \& Snell, S. A. (1998). Toward a unifying framework for exploring fit and flexibility in strategic human resource management. Academy of Management Review, 23, 756-772. 